\title{
Validating Local Drivers Influencing Land Use Cover Change (LUCC) in Southwestern Ghana: A Mixed-Method Approach (MMA) Analysis.
}

Isaac Sarfo ( $20195129001 @$ @uist.edu.cn )

Nanjing University of Information Science and Technology https://orcid.org/0000-0002-6914-5764

Bi Shuoben

Nanjing University of Information Science and Technology School of Remote Sensing and Geomatics Engineering

Henry Bortey Otchwemah

University of Reading

George Darko

Nha Trang University

Emmanuel Adu Gyamfi Kedjanyi

Nanjing University of Information Science and Technology

Collins Oduro

Nanjing University of Information Science and Technology

Ewumi Azeez Folorunso

University of South Bohemia Faculty of Fisheries and Protection of Waters: Jihoceska Univerzita v Ceskych Budejovicich Fakulta Rybarstvi a ochrany vod Mohamed Abdallah Ahmed Alriah

Nanjing University of Information Science and Technology

Solomon Obiri Yeboah Amankwah

Nanjing University of Information Science and Technology School of Remote Sensing and Geomatics Engineering

Grace Chikomborero Ndafira

Nanjing University of Information Science and Technology

\section{Research Article}

Keywords: Land use, contribution rate, confidence level, AHP, Southwestern Ghana

Posted Date: January 31st, 2022

DOI: https://doi.org/10.21203/rs.3.rs-947297/v1

License: (a) (1) This work is licensed under a Creative Commons Attribution 4.0 International License. Read Full License 


\section{Abstract}

Addressing undesirable changes associated with the driving forces of land use cover change are critical to sustainable land management, and the future modelling of land use systems in developing countries. The study ascertains local drivers of land-use cover change in Southwestern Ghana using a mixedmethod approach. The approach aided in identifying key land-use drivers, using different research strategies for comparisons through confidence level analysis and Analytic Hierarchy Process. We used expert interviews, existing literature and geostatistical tools to ascertain the driving forces triggering such unprecedented changes. Landsat imagery 5 MSS, 4 and 5 TM, 7 ETM+ and 8 OLI/TIRS were acquired from the United States Geological Survey's website. Land use analysis revealed a decline in forests $\left(-334.8 \mathrm{~km}^{2} \mathrm{yr}^{-1}\right.$.) and areas covered by waterbodies (-4.79 $\mathrm{km}^{2} \mathrm{yr}^{-1}$.). A remarkable increase in built-up $\left(+137.93 \mathrm{~km}^{2} \mathrm{yr}^{-1}\right.$.) and farmlands/shrubs $\left(+131.97 \mathrm{~km}^{2} \mathrm{yr}^{-1}\right.$.) areas were also observed. The contribution rate of change analysis revealed built-up areas and increasing population contributed the most to surface temperature and land use change. A steady increase in surface temperature can be attributed to the undesirable changes associated with land-use systems over the past 50 years. Socio-economic development in Southwestern Ghana is fuelling interest in studies related to land use cover change. Biophysical, cultural and technological factors are considered key drivers despite the "medium-to-very low confidence" in results generated. They could potentially impact climate-sensitive sectors that significantly modify land-use systems from the pessimists and optimists' perspectives. Standpoints established through this study will enrich basic datasets for further studies at the continental level.

\section{Introduction}

Land use and forest management remain pivotal in achieving the United Nations' Sustainable Development Goals (SDGs). Studies have comprehensively reflected on the linkage between 'Sustainability' and Forest Transition Theory 'FTT' (Rudel et al. 2010; Turner et al. 2007; Mather et al. 1998). When viewed through the lens of the SDGs, making gains in FTT application may complement global efforts at achieving SDGs 1 (No Poverty), 2 (End Hunger), 13 (Climate Action), and 15 (Life on Land) in various ways. Meyfroidt and Lambin (2011), in their research on FTT, reinforced the connection between land use change dynamics and the FTT concept, as echoed by Foley et al. (2005). Arguably, both studies implicitly and explicitly provide opportunities for forest transition to 'reinstate' poorer, forest dependent populations into more favourable socio-economic positions as access to natural capital becomes possible. This must however, be supported by enabling factors, mainly a corruption free system. There is also a possibility for a non-realisation of the 'full potential' of natural resource access alone in reducing poverty, considering arguments brought forward by studies which explore the five capitals model (Gazzola and Querci, 2017; Sim et al. 2004; Angelsen and Wunder 2003; Smith and Scherr 2002; Hyden 1998). They argued that effective poverty reduction is achieved when access to all five capitals (Gazzola and Querci 2017) exist, hence, possibly undermining positive forest transition outcomes in poverty alleviation; highly possible in the tropics and less developed countries.

Systems responsible for sustainable use of forest resources are essential (Damnyag et al. 2017; FAO 2013) in themselves, and for contributing to forest transition (Waggoner and Ausubel 2001). In the same vein, forest transition can contribute to sustainable forest resource management (Lambin and Meyfroidt 2011). Land cover (LC) requires robust use of the elements of Sustainable Forest Management (SFM); "biomass; flora and fauna; forest health and vitality; productive functions of forest resources; conservative functions of forest resources; ecosystem services; legal, policy and institutional framework" (FAO 2013). Various studies support the central idea that efforts geared at the SFM elements remain critical for a fair forest resource use regime across all facets of socioeconomic status, underscored by transparency in the context of forest transition (Rudel et al. 2020; Southworth et al. 2012; Lambin and Meyfroidt 2011; Meyfroidt and Lambin 2011). Concepts of "ecoconsumerism" (Meyfroidt and Lambin 2011), and "new corporate environmentalism" (Nasi and Frost 2009), reemphasise rigorous SFM approaches through forest transition. These ensure land cover related benefits mainly ecosystem/ecological service advantages, and forest product use benefits become, and remain (if existent), reality.

The human-environment relationship varies in time and space. Land Use Cover Change (LUCC) is often caused by an interplay of multiple factors (Tolessa et al. 2019; Lambin and Meyfroidt 2011; Sim 2004). The dynamic interactions result in the formation of undesirable changes associated with LUCC. In response to the growing demands of human survival and developmental needs, the earth 's surface is continuously altered. Historically, LUCC in the current age-ofanthropocene, evolve from multiple direct and indirect factors (Mensah et al. 2019; Acheampong et al. 2018). These events accelerated substantially with the evolution of farming activities, resulting in the massive clearance of pristine environments. More recently, structural economic policies have driven industrialization, forcing people to migrate to urban centres, thereby resulting in the depopulation of rural areas. This is accompanied by the intensification of agriculture in the most productive lands, and neglect of marginal lands (Damnyag et al. 2017; Saad et. al. 2013; Kusimi 2008). When land is transformed from a primary forest to a farm, the loss of forest species within deforested areas occurs. Similarly, undisturbed environments are relatively transformed to more intensive uses, including livestock grazing, selective tree harvest, among others (Ellis and Pontius 2010). Some areas are often left bare, exposing such areas to unfavourable conditions which often leads to rending these areas unproductive.

In recent years, different scholars have applied useful techniques to study LUCC across Ghana. They primarily focused on changes in and around reserves/catchment areas (Gockowski and Sonwa, 2011; Alo and Pontius, 2008), spatial determinants of classes, dynamisms in future modelling (Addae and Oppelt, 2019; Koranteng et al.2017), along with establishing links between demographic changes and land use systems (Moller-Jensen and Knudsen, 2006). Others researchers have conducted meta-analysis or review studies on land use systems and water sedimentation (Boakye et al., 2018). Local studies conducted in various towns, districts and regions have assessed impacts of urbanization, illegal logging of trees and intensiveness of large scale mining and artisanal or small-scale mining (LSM/ASM) (Owusu-Nimo et al., 2018; Awotwi et al. 2018; Basommi et al. 2015), urban heat islands (Aduah et al. 2012), driving forces and consequences in regional capitals; notably Bolgatanga, Accra, Kumasi (McGregor, 2011), Sekondi-Takoradi (Obeng-Odoom, 2013) among other municipalities/towns like Kintampo Municipality (Bessa et al. 2019) and New Juaben, respectively. Watershed and other river basin studies around Lake Bosomtwe (Bessa et al. 2020; Amproche et al. 2019; Awotwi et al. 2015; Adjei et al. 2014; Leemhuis et al. 2009) in the Ashanti region of Ghana; Black and White Volta River Basins in the Volta/Oti regions (Tahiru, 2020) in the far east; Ankobra, Pra and Densu River Basins (Oti et al., 2020) in the west and Southernmost part of Ghana assessed the impacts of illegal mining (primarily gold and bauxite mining), deforestation among other factors that induce land cover transitions in these areas. The Southwestern region of Ghana hosts two-thirds of the country's high forest zone, and is most endowed in natural

Page 2/35 
resources among the sixteen (16) administrative regions in Ghana. The agricultural and mineral sectors are critical to the growth and development of Ghana's economy. Considering Southwestern Ghana's contribution to the country's overall Gross Domestic Product (GDP), the region produces almost two-thirds of Ghana's cocoa (contributing about $30 \%$ of the country's export earnings) among other cash crops, as well as gold, bauxite, diamond and manganese (OwusuNimo et al., 2018; Asante-Poku, 2013). Ghana is Africa's leading gold producer (generated about 6.2 billion US dollars revenue from exports) unseating South Africa in 2019, coupled with being the second largest producer of cocoa in Africa with discovery of several oil fields for exploration (Geiger et al. 2019). These major commodities that contribute significantly to the country's GDP remain the main stay of the study area and the country at large. We sought to ascertain the main drivers of LUCC in Southwestern Ghana using the mixed-method approach (MMA) (1970-2020). Ineffective monitoring and regulation of these drivers, could further exacerbate land degradation in the region. This could hamper productivity levels that will influence the country's GDP. The MMA employs both qualitative and quantitative strategies to identify and analyse both direct and indirect factors that influence LUCC. It does not solely detect changes, but also validates information on dynamics in environmental issues that provide strategic directions for policy-makers, and inform the choices of local communities. Contextually, only few studies have attempted to quantify non-spatial/indirect drivers of LUCC (Kleemann et al. 2017; Jacobs et al. 2015; MA 2005). Long term residents and expert opinions are key in understanding why LULD in the study area is constantly changing, since the triggering effects constitute direct and indirect forces. Kleemann et al. (2017) focused on urbanization and patterns of change in two regional capitals, both in the northern and southern part of Ghana. This regional study further introduces the contribution rates of Normalized Difference Vegetation Index (NDVI) and Normalized Difference Built-up Index (NDBI) to temperature variations. Additionally, it sought to adopt the Analytical Hierarchy Process (AHP) to compare and assign weights to experts' judgements in the validation of the key drivers. Hence, employing the MMA to quantify both spatial and non-spatial drivers, aimed to enhance comparisons, consistency and confidence in study findings. In the frame of this research, we attempted to address the following research questions:

i. What direct and indirect factors influence LUCC in Southwestern Ghana?

ii. What is the contribution rate of change for each class within the various indices against surface temperature?

iii. How consistent are the findings of expert interviews and literature review, against results from geospatial analysis that could drive land cover transitions and land degradation?

iv. Does consistency in the study approach enhance confidence and validity in findings that could be used to test existing theories?

Studies on land use assessments require a large amount of spatial data and other qualitative tools for effective evaluation and prioritization of alternative decisions. The novelty of this study dwells on the application value of concepts/applications, aimed at identifying and assessing local drivers influencing LUCC in Southwestern Ghana. We replicated and tested the approach, introduced by IPCC's fifth AR5 Working Group. The integrated approach is holistic, and can be tested in other areas.

\section{Methodology 2.1 Study area}

The study was conducted in Southwestern Ghana as part of a broad study that analysed spatiotemporal development of land use systems and climate variability in Ghana between 1970 and 2020 . The study domain (Fig. 1) is located on latitude $5.3902^{\circ} \mathrm{N}$ and longitude $2.1450^{\circ} \mathrm{W}$. It currently covers an approximate surface area of $23,921 \mathrm{~km}^{2}$ (9,236 sq. mi) representing about 10 percent of Ghana's total land surface area. About 75 per cent of Ghana's high forest vegetation among other natural resources can be found in the region. The study area hosts two administrative regions; Western North and Western region.

\subsection{Image classification}

In this study, six Landsat images archived for the given period (1970-2020) (Table 1) from Landsat 5 MSS, Landsat 4 TM, Landsat 5 TM, Landsat 7 ETM+ and Landsat 8 OLI/TIRS were acquired from the United States Geological Survey's (USGS) website (http://earthexplorer.usgs.gov/). ArcGIS 10.6, ENVI 5.0 and 5.3 were used for the image pre-processing. Other image processing and enhancement procedures constituted image mosaicking, calibration, layer stacking, region of interest (ROI) and supervised classification (Table 2) were performed to rectify atmospheric effects and distortions in images. A Maximum Likelihood Classification Algorithm (MLCA) was employed for preliminary classifications based on the results of the supervised classification (Fig. 2).

Table 1

Description of imagery data used for LUCC study in Southwestern Ghana

\begin{tabular}{|llllll|}
\hline Imagery type & Year Acquired & Resolution & Data Source & Path & Row \\
\hline LANDSAT 5 MSS & $1970 \mathrm{~s}$ & $30 \mathrm{~m}$ & USGS & $194 / 195 / 208 / 209$ & $054 / 055 / 056$ \\
\hline LANDSAT 4 TM & $1980 \mathrm{~s}$ & $30 \mathrm{~m}$ & USGS & $194 / 195 / 208 / 209$ & $054 / 055 / 056$ \\
\hline LANDSAT 5 TM & $1990 \mathrm{~s}$ & $30 \mathrm{~m}$ & USGS & $194 / 195 / 208 / 209$ & $054 / 055 / 056$ \\
\hline LANDSAT 7 ETM+ & 2000 & $30 \mathrm{~m}$ & USGS & $194 / 195 / 208 / 209$ & $054 / 055 / 056$ \\
\hline LANDSAT 7 ETM+ & 2010 & $30 \mathrm{~m}$ & USGS & $194 / 195 / 208 / 209$ & $054 / 055 / 056$ \\
\hline LANDSAT 8 OLI/TIRS & 2020 & $30 \mathrm{~m}$ & USGS & $194 / 195 / 208 / 209$ & $054 / 055 / 056$ \\
\hline
\end{tabular}




\begin{tabular}{|ll|}
\hline Land Cover & Description \\
\hline Forests & $\begin{array}{l}\text { Areas dominated by closely knit trees and luxurious vegetative cover. It also encompasses all vegetative areas that expose no } \\
\text { bare soil. }\end{array}$ \\
\hline $\begin{array}{l}\text { Built-up } \\
\text { areas }\end{array}$ & $\begin{array}{l}\text { Residential, commercial and industrial areas are classified } \\
\text { as built-up areas. Parks, gardens, playing grounds and lorry stations within communities also fall under this class. }\end{array}$ \\
\hline Bare land & $\begin{array}{l}\text { These are usually patches of land or rocks which are not covered by vegetation. Bare lands are common in and near built-up areas. Lands } \\
\text { that have been cleared in readiness for building or farming fall under this class. }\end{array}$ \\
\hline $\begin{array}{l}\text { Farmlands } \\
\text { and shrubs }\end{array}$ & $\begin{array}{l}\text { Describes all areas that portray sparsely located trees, } \\
\text { shrubs, isolated thickets and areas with non-tree crops. }\end{array}$ \\
\hline Water bodies & Comprise rivers, lagoons, lakes and so on. \\
\hline
\end{tabular}

Table 3

Combinations between agreement and evidence levels for each finding. Each level is defined for the respective method (RS= remote sensing; expert interviews; literature review).

\begin{tabular}{|lll|}
\hline Symbol & Level of Agreement & Details \\
\hline$\sqrt{ } \sqrt{ }$ & High Agreement & Statement is confirmed within one method. \\
$\sqrt{ }$ & Medium Agreement & -for expert interviews: $>60 \%$ of respondents confirmed \\
$\mathrm{x}$ & Low Agreement & -for literature: more than two sources confirmed \\
& & -for RS: if study was conducted in the same area with similar scope. Otherwise, not applicable. \\
& Statement is confirmed but limited data within one method \\
& -for expert interviews: $25-60 \%$ of respondents confirmed \\
& -for literature: one or two sources confirmed \\
& -for RS: Confirmed \\
& Confirmation and rejection within one method \\
& -for expert interviews: <25\% of respondents confirmed \\
& -for literature: confirmation and rejection balanced \\
\hline Level of evidence & No data or evidence \\
\hline High evidence & Details \\
Medium evidence & Tho methods can provide information \\
Low evidence & One method can provide information. \\
\hline
\end{tabular}

\subsection{Change Detection Analysis}

Change detection analysis was run to ascertain the regularity of land use systems, and its drivers in southwestern Ghana (1970-2020). The present study applied image differencing, NDVI, post-classification and Geographic Information System (GIS) techniques in determining the spatiotemporal development of land use systems in the area. LUCC was computed based on the following expressions:

$$
\begin{gathered}
\text { ChangeinLUCC }\left(\mathrm{x}^{2}\right)=\frac{\text { LUCC }_{\text {Currentyear }}-\text { LUCC }_{\text {Pastyear }}}{\text { LUCC }_{\text {Pastyear }}} \cdots \text { Eqn1 } \\
\text { I\%ChangeinLUCC }\left(\mathrm{x}^{2}\right)=\frac{\text { LUCC }_{\text {Currentyear }}-\text { LUCC }_{\text {Pastyear }}}{\text { LUCC }_{\text {Pastyear }}} \times 100 \backslash \% \cdots \text { Eqn2 } \\
\text { RateofChangeinLUCCperyear }=\left[\left(\frac{\text { LUCC }_{\text {Currentyear }}-\text { LUCC }_{\text {Pastyear }}}{\text { LUCC }_{\text {Pastyear }}}\right) \times 100 \backslash \%\right] \div 50 \text { years } \cdots \text { Eqn3 }
\end{gathered}
$$

The change detection statistics for the study period (1970-2020) was obtained using pixel count, area in $\mathrm{km}^{2}$ and percentages for the purpose of analysis. This facilitated the generation of statistical data of change occurrence over the years in relation to each class.

\subsection{Temperature analysis}

\subsubsection{Image Calibration (Radiance)}


Radiometric correction (radiance) was done to rectify atmospheric effects and enhance clarity. Gap-filling was performed to remove stripes in images. Distortions in images were removed during the calibration process (Coll et al., 2010). Using the mathematical expression:

$$
\mathrm{L}_{\lambda}=\frac{\left(\mathrm{LMAX}_{\lambda}-\mathrm{LMIN}_{\lambda}\right)}{(\mathrm{QCALMAX}-\mathrm{QCALMIN})} \mathrm{x}(\mathrm{DN}-\mathrm{QCALMIN})+\mathrm{LMIN}_{\lambda} \cdots \mathrm{Eqn} .4
$$

Where $\mathrm{L}_{\lambda}$ is cell value as radiance in $W /\left(M^{2} * s r * \mu m\right)$;

$L M A X_{\lambda}$ is the sensor spectral radiance that is scaled to $(Q C A L M A X)$ in $W /\left(M^{2} * S r * \mu m\right) ; L M I N_{\lambda}$ is the sensor spectral radiance that is scaled to $(Q C A L M I N)$ in $\left[W /\left(M^{2} * s r * \mu m\right)\right]$. (QCALMAX) is the maximum quantized calibrated pixel value to $L M A X_{\lambda}$ [DN], (QCALMIN) is the minimum quantized calibrated pixel value corresponding to $L M I N_{\lambda}$ [DN]; and QCAL is the quantized calibrated pixel value [DN]. Equation 4 can be observed from header files ETM+ and TM datasets from USGS website. The LMIN and LMAX are the spectral radiances for each band at digital numbers (DN) 1 and 255 for Landsat 7 ETM+, 1 and 65535 for Landsat 8 OLI/TIRS. $\lambda$ is the wavelength.

Conversion of Spectral Radiance $\left(L_{\lambda}\right)$ to Kelvin with emissivity value:

$$
\mathrm{T}=\frac{\mathrm{K}_{2}}{\ln \left(\frac{\mathrm{K}_{1} * \mathrm{E}}{\mathrm{L}_{\lambda}}+1\right)} \cdots \text { Eqn. } 5
$$

Therefore, $k_{1}$ and $k_{2}$ become coefficients determined by effective wavelength of a satellite sensor (Avdan \& Jovanovska 2016; Ghulam, 2010).

$$
\mathrm{BT}=\frac{\mathrm{K}_{2}}{\ln \left[\left(\mathrm{K}_{1} / \mathrm{L}_{\lambda}\right)+1\right]} \cdots \operatorname{Eqn} .6
$$

\subsubsection{Conversion of Spectral radiance $\left(L_{\lambda}\right)$ to Kelvin with emissivity value from Landsat 8}

Since temperature is required in Degree Celsius $\left({ }^{\circ} \mathrm{C}\right)\left(T_{C}\right)$, results for various temperatures must be converted from Kelvin $(K)\left(T_{B}\right)$ to degree Celsius $\left({ }^{\circ} \mathrm{C}\right)\left(T_{C}\right)$ :

$$
\mathrm{T}_{\mathrm{C}}=\mathrm{T}_{\mathrm{B}}-273.15 \cdots \text { Eqn. } 7
$$

Where $T_{B}$ is value at satellite brightness temperature $(K)$ and $T_{C}$ is temperature in Degree Celsius.

\subsubsection{Contribution rate of change for the various indices}

Reclassification was performed for the understudied indices (NDVI and NDBI) over the given study period (1970-2020). Five classes were generated for each of the indices for each period using ArcMap. The classes were obtained based on value range results from high to low considering the output of the indices. The classes were reclassified based on their value range using the identification tool in ArcMap. This resulted in the identification and classification of forests, farmlands/shrubs, water bodies, bare land and built-up value range within the understudied indices.

After obtaining the various classes based on the value range, the zonal geometry tool in ArcMap was used to obtain the area coverage in square meters for each class. The table obtained was exported to Statistical Package for Social Sciences (SPSS Inc. Chicago, USA, version 16) for conversion of the area (sq.km), percentage contributions of the various classes for the various indices, along with existing changes in terms of area coverage for the given years. Using the expressions:

$$
\mathrm{NDVI}=\frac{(\mathrm{NIR}-\mathrm{RED})}{(\mathrm{NIR}+\mathrm{RED})} \cdots \mathrm{Eqn} .8
$$

where; NIR= Near-infrared, RED= Red visible bands (Xu, 2007). Again, Normalized Difference Built-up index (NDBI) was expressed as:

$$
\mathrm{NDBI}=\left(\frac{(\text { SWIR }-\mathrm{NIR})}{(\mathrm{SWIR}+\mathrm{NIR})}\right) \quad \ldots \text { Eqn.9 }
$$

For Landsat 7 data, NDBI $=($ Band $5-$ Band 4$) /($ Band $5+$ Band 4$)$.

$$
\text { ContributionRateofChange }(C R C)=\frac{L U C(s q . k m)_{\text {Present } / \text { futureyear }}}{L U C(s q . \mathrm{km})_{\text {Past } / \text { Previousyear }}}-1 \ldots \text { Eqn10 }
$$

Where: $\mathrm{CRC}=$ contribution rate of change for a given class, over a given study period among the understudied indices, whilst LUC=land use class. Here, the value of change for each class given the output indicates the rate of change/contribution. High positive values indicate an increment (rate of contribution) in area coverage for a particular class over the given study period. Contrarily, negative values represent a decline (rate of contribution) in area coverage for a 
given class. Considering the expression above (Eqn. 10), the rate of change (+/-) based on the results generated will indicate which class contributed the most towards change in the area.

\subsection{Data Analysis}

The MMA approach was primarily used in IPCC's fifth assessment report to validate the inconsistencies, associated with the various working groups' reports on indirect drivers of LUCC (Kleemann et al. 2017; Jacobs et al. 2015). A semi-structured questionnaire was designed and administered to some experts in the study area. "Experts" in this study is defined as individuals with extensive knowledge and experience in relation to the scope of this study, and have lived or worked in the area for more than 20 years. In-depth interviews were conducted among 30 experts to ascertain the major drivers of LUCC. Experts were chosen based on willingness and availability to contribute to the study.

Excel and Statistical Package for SPSS v.16 software were employed to capture, clean and analyse the data collected. Results from respondents' knowledge were used to validate the outcome of satellite imagery and existing literature over the given study period.

\subsubsection{Confidence Level Analysis}

To express the validity and reliability of findings, we adopted the confidence level approach provided by Kleemann et al. (2017), Jacobs et al. (2015), based on Mastrandrea et al. (2011) for the IPCC AR5 and the Millennium Ecosystem Assessment (MA, 2005). They established synergy between agreement and evidence levels to examine confidence in avouching study findings (Tables 4 and 5). This parameter is important in correcting the degree of inconsistencies or inaccuracies in various approaches used. The present study moves further to introduce contribution rates of various indices to changes in temperature and LUCC, coupled with AHP to assign weights to expert judgements, which were not employed in the aforementioned studies.

Table 4

Confidence level table of findings from interviews, remote sensing and existing literature

\begin{tabular}{|l|l|l|l|}
\hline Level of confidence & Limited evidence & Medium evidence & Robust evidence \\
\hline High Agreement & Medium & High & Very High \\
\hline Medium Agreement & Low & Medium & High \\
\hline Low Agreement & Very low & Low & Medium \\
\hline
\end{tabular}

Adapted from Kleemann et al. (2017) and Jacobs et al. (2015) based on Mastrandrea et al. (2011) and MA (2005).

Table 4.1

Saaty's (1980) scale for comparison of various elements.

\begin{tabular}{|lll|}
\hline Scale & Judgement of Preference & Description \\
\hline 1 & Equally important & Two factors contribute to the objectives \\
\hline 3 & Moderately important & Experience and judgement slightly favor one over the other \\
\hline 7 & Important & Experience and judgement strongly important favor one over the other \\
\hline 9 & Very strongly important & Experience and judgement strongly important favor one over the other \\
\hline $2,4,6,8$ & Extremely important & The evidence favoring one over the other is of the highest possible validity \\
\hline $1 / 3,1 / 5,1 / 7,1 / 9$ & Values for inverse comparison & When compromised is needed \\
\hline
\end{tabular}

Table 4.2

Random index matrix of the same dimension

\begin{tabular}{|lllllllllll|}
\hline No. of Criteria & $\mathbf{2}$ & $\mathbf{3}$ & $\mathbf{4}$ & $\mathbf{5}$ & $\mathbf{6}$ & $\mathbf{7}$ & $\mathbf{8}$ & $\mathbf{9}$ & $\mathbf{1 0}$ & $\mathbf{1 1}$ \\
\hline $\mathrm{RI}$ & 0.00 & 0.58 & 0.90 & 1.12 & 1.24 & 1.32 & 1.41 & 1.45 & 1.49 & 1.51 \\
\hline
\end{tabular}


Table 5

Biodata of respondents in Southwestern Ghana

\begin{tabular}{|c|c|c|c|}
\hline Characteristics & Variables & Frequency $(n=30)$ & Percentage (\%) \\
\hline \multirow[t]{2}{*}{ Gender } & Male & 26 & 86.7 \\
\hline & Female & 4 & 13.3 \\
\hline \multirow[t]{4}{*}{ Age limit } & $18-25$ & - & - \\
\hline & $26-40$ & 16 & 53.3 \\
\hline & $41-65$ & 14 & 46.7 \\
\hline & $>65$ & - & - \\
\hline \multirow[t]{4}{*}{ Educational Status } & No formal education & - & - \\
\hline & Primary & - & - \\
\hline & Secondary & 8 & 26.7 \\
\hline & Tertiary & 22 & 73.3 \\
\hline \multirow[t]{4}{*}{ Length of stay/work period } & $<5$ years & - & - \\
\hline & $5-15$ years & 8 & 26.7 \\
\hline & $16-40$ years & 22 & 73.3 \\
\hline & $>40$ years & - & - \\
\hline QN Institution & Role/Capacity & Research Interests & \\
\hline
\end{tabular}

The distribution above presents the institution/affiliation, role and research interests of the 30 experts who were interviewed using the semi-structured questionnaire. Location $(T)=$ Takoradi, SW Ghana, $(E)=$ Enchi, SW Ghana; QN=Questionnaire number; $(*)=$ same institution 


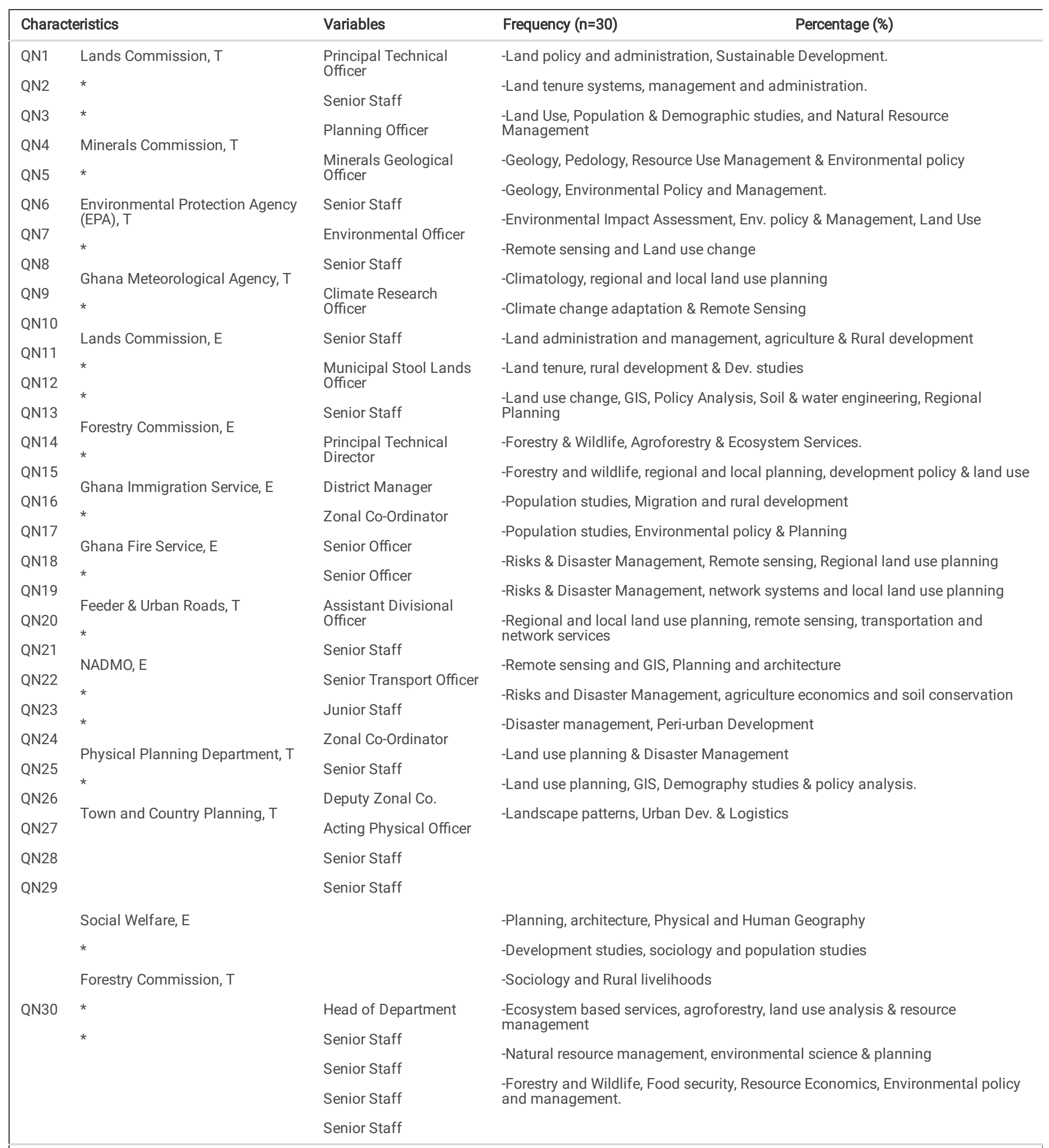

The distribution above presents the institution/affiliation, role and research interests of the 30 experts who were interviewed using the semi-structured questionnaire. Location(T)=Takoradi, SW Ghana, $(E)=$ Enchi, SW Ghana; QN=Questionnaire number; $(*)=$ same institution

\subsection{Analytical Hierarchy Process (AHP) model}

The AHP is an analytical tool used to illustrate a phenomenon, examine and advance priorities, based on the user's discretion with the aim of solving complex problems (Saaty, 1980). AHP analysis employs six steps (Saaty, 1980) enhanced by Danumah et al. (2016): Breaking a complex unstructured problem down into its component factors; formulation of hierarchical structure; paired comparison matrix determined by coercing results; allocating values to subjective judgments and measuring the relative weights of each criterion; systemize results to determine the priority variables, and look-out for consistency in assessments and judgments. The unique basic quality of AHP is the calculation of consistency ratio which reduces bias to a larger extent, and determine how 
logical results are. If consistency ratio is less than or equal to 0.1 , then the factor is considered as acceptable consistency. However, AHP approach is built on three levels as evident in Fig. 3. Level 0 (main objective); Level 1 (criteria analysis which constitute biophysical and proximate/underlying factors) whereas Level 2 lists the elements associated with Level 1 (Danumah et al, 2016; Nejad et al. 2015; Chakraborty \& Joshi, 2014). In this study, criteria weightings were assigned to judgements from experts to draw a logical conclusion on validating local drivers that influences LULD in Southwestern Ghana.

\subsubsection{Principles for selecting each weight factor (AHP)}

The ideal intent is to design a matrix that exhibits relative values of Level 2 elements in a hierarchy. Expert opinions or judgments are assigned a number according to Saaty's scale. A simple, but very pragmatic assumption is that if for instance, element $A$ is very strongly crucial than element $B$, then $A$ is assigned or valued as 7. B becomes less important than $A$, hence, $B$ is valued at $1 / 7$. A pair-wise comparison was done for all the listed factors. Again, relative weights were calculated (eigenvector).

\subsubsection{Pairwise Comparison}

The binary combination is based on Saaty's (1980) proposition to compare key and potential drivers whilst the pairwise comparison is the basic element of AHP process. For pairing in each criterion, the preferable element is weighted on a scale ranging from 1 (equally good) to 9 (absolutely better), whereas the less preferred element is assigned a weight, reciprocal to this value. Each score illustrates how better element " $\mathrm{X}$ " meets criterion " $Y$ ". The ratings are normalized, and their consistency are being calculated (Table 4.1).

\subsubsection{Development and Prioritization Matrix}

Developing and prioritizing matrix are done to ascertain the eigenvectors (Vp) of each criterion for each item as expressed in eqn.11;

$$
V_{p}=n \sqrt{W 1 x \ldots} W n \ldots e q n(11)
$$

$\mathrm{n}$ represents the number of parameters. Wn ratings are the main parameters. The criteria weight $(\mathrm{Cp})$ is measured as:

$$
C_{W}=\frac{V_{p}}{V_{p} 1+\cdots+V_{p n}} \ldots \operatorname{eqn}(12)
$$

The sum of criteria weights $\left(\mathrm{C}_{\mathrm{w}}\right)$ of all parameters of a matrix equals 1 and expressed as a percentage. Normalize the matrix by dividing each element by the sum of the column, and calculate the mean of each line to determine the priority vector [C]. $\lambda$ is calculated by averaging the value of the consistency vector. It is generated from the summation of products between each element of Eigen vector and the normalized relative weight. $\lambda$ max (eqn.13); $\mathrm{Cl}$ (eqn.14) and $\mathrm{CR}$ (eqn.15) are calculated as:

$$
\begin{gathered}
\lambda \max =\frac{[E]}{n} \ldots \text { eqn }(13) \\
C I=(\lambda \max -\mathrm{n}) /(\mathrm{n}-1) \ldots \text { eqn }(14)
\end{gathered}
$$

The ratio of consistency is the probability that the croak is completed randomly. When $\mathrm{CR} \leq 10 \%$, the results are considered to be pragmatic. However, a CR > 0.1 indicates the need for revision.

$$
C R=\frac{C I}{R I} \ldots e q n(15)
$$

The random index (RI) estimations are presented in Table 4.2

\subsection{Accuracy Assessment: Ground Truthing exercise}

Ground truthing sampled points were taken using a Mobile Data Collection Application (MDC). The samples were imported unto the Southwestern Ghana shapefile in ArcMap for verification. Samples taken for each class (Table 2) were divided/distributed based on area coverage. Thus, bare land (70), built-up areas (177), waterbodies (20), forests (104) and farmlands/shrubs (153) sampled points were taken from the field, making a total of five hundred and twentyfour (524) samples (Fig. 4 and Fig. 5). We designed a sampled collection form using a licensed GIS Cloud for the ground-truthing exercise. Using a confusion matrix, we assessed and improved the user and producer's accuracy assessment technique that culminates randomized, and overall sampled points. The mathematical expression (Eqn.16) adapted from Sarfo et al. 2021, was used in calculating the accuracy assessment:

$$
\text { AccuracyAssessment }(\mathbf{A} . \mathbf{A})=[(\mathrm{ASP} / \mathrm{TSP}) \times 100 \cdots \text { Eqn. 16] }
$$

where:ASP $=$ Number of sample points that accurately falls on each required feature $(A S P=493) . T S P=$ Number of total sample points generated $(\mathrm{TSP}=524) \cdot A \cdot A=$ Accuracy Assessment $[(493 / 524) \times 100=94.08 \%]$.Therefore, the present study had $94 \%$ accuracy over the study period considering the samples collected.

Figures 4 and 5 depict areas where the sampled points (524) were taken using the Mobile Data Collection (MDC) Application (see Annex II), as well as areas where the questionnaires were administered. Considering the characteristics of Southwestern Ghana as presented in section 2.1 (Fig. 1), the sample size for 
each land class was determined based on the dominance or proportion of coverage of each land cover. Random sampling was performed to obtain information for each class.

\section{Results}

\subsection{Sociodemographic characteristics of respondents}

Majority of the respondents interviewed were males (87\%) whilst the remaining quota (13\%) represented females in Southwestern Ghana (Table 5). The distribution below (Table 5) shows $53 \%$ of respondents had an age range of $26-40$ years while $47 \%$ ranged between $41-65$ years. In terms of educational background, $27 \%$ of respondents had attained secondary education while $73 \%$ had obtained tertiary education with various degrees. Also, most ( $73 \%$ ) of the respondents had been living or working in the study area for $( \pm 28)$ years. The remaining quota $(27 \%)$ on the other hand, asserted they have been living or working in the area for $( \pm 10)$ years

\subsection{Change Detection Analysis: Drivers of Land Use Cover Change}

An array of factors that influence land cover types from the local to the global level are often anthropocentric and biophysical in nature. We identified over eight (8) major factors (proximate/ underlying) that drive LUCC in Southwestern Ghana (Table 7 and Table 9, Fig. 6). Results presented in Table 6 shows an area coverage (sq.km) for each class and evidence of considerable LUCC patterns in Southwestern Ghana between 1970 and 2020 (Fig. 6). The main land use features that increased progressively over the study period were built-up and farmlands/shrubs (Fig. 7 and Fig. 10-11). Additionally, bare land, waterbodies and forest areas experienced dynamic ebb over the given period.

Table 6

Area coverage for LUCC in Southwestern Ghana (1970-2020)

\begin{tabular}{|c|c|c|c|c|c|c|}
\hline \multicolumn{7}{|c|}{ Area coverage for each class $\left(\mathrm{km}^{2}\right)$ over the given period $(1970-2020)$} \\
\hline LUCC class & 1970s & $1980 \mathrm{~s}$ & $1990 \mathrm{~s}$ & 2000 & 2010 & 2020 \\
\hline Bare land & 417.63 & 320.91 & 2607.63 & 2134.04 & 1928.93 & 1607.11 \\
\hline Built-up areas & 535.26 & 623.636 & 750.81 & 3278.45 & 4843.33 & 8212.04 \\
\hline Waterbodies & 874.48 & 3120.54 & 2420.37 & 1708.19 & 1330.68 & 1192.43 \\
\hline Farmlands and Shrubs & 1784.22 & 5632.85 & 8002.66 & 11093.37 & 10283.95 & 10391.86 \\
\hline Forests & 20312.42 & 14226.92 & 10991.20 & 6124 & 4439.02 & 1628.13 \\
\hline Total & 23924.01 & 23924.86 & 24772.67 & 24333.05 & 22835.91 & 23031.57 \\
\hline \multicolumn{7}{|c|}{ Contribution rate of change for NDBI } \\
\hline \multirow[t]{2}{*}{ Class/Period } & $1970 s-1980 s$ & $1980 \mathrm{~s}-1990 \mathrm{~s}$ & $1990 s-2000$ & $2000-2010$ & $2010-2020$ & $1970 s-2020$ \\
\hline & CRC & CRC & CRC & CRC & CRC & CRC \\
\hline Forests & -0.04 & 0.06 & -0.12 & -0.11 & -0.18 & -0.34 \\
\hline Farmlands/shrubs & 0.17 & -0.14 & 0.17 & 0.11 & 0.03 & 0.33 \\
\hline Waterbodies & -0.36 & 0.14 & -0.25 & 0.17 & 0.00 & -0.55 \\
\hline Bare land & -0.43 & 0.25 & 0.33 & -0.50 & 0.00 & -0.71 \\
\hline Built-Up & 2.00 & 0.33 & 0.25 & 0.40 & 0.43 & 9.00 \\
\hline \multicolumn{7}{|c|}{ Contribution rate of change for NDVI } \\
\hline \multirow[t]{2}{*}{ Class/Period } & $1970 \mathrm{~s}-1980 \mathrm{~s}$ & $1980 \mathrm{~s}-1990 \mathrm{~s}$ & $1990 s-2000$ & $2000-2010$ & $2010-2020$ & $1970 \mathrm{~s}-2020$ \\
\hline & CRC & CRC & CRC & CRC & CRC & CRC \\
\hline Forests & -0.17 & 0.07 & -0.06 & -0.04 & -0.12 & -0.30 \\
\hline Farmlands/shrubs & 0.35 & 0.03 & -0.03 & 0.09 & 0.05 & 0.54 \\
\hline Waterbodies & -0.47 & 0.40 & -0.14 & -0.50 & -0.33 & -0.79 \\
\hline Bare land & 0.13 & -0.78 & 1.00 & -0.50 & 0.00 & -0.75 \\
\hline Built-Up & 1.40 & 0.17 & 0.43 & 0.40 & 0.29 & 6.20 \\
\hline \multicolumn{7}{|c|}{ Population Growth (million) for Southwestern Ghana } \\
\hline Region/Period & 1960 & 1970 & 1984 & 2000 & 2010 & 2020 \\
\hline Southwestern Ghana & 625,155 & 770,087 & $1,157,807$ & $1,924,577$ & $2,376,021$ & $3,093,200$ \\
\hline \multicolumn{7}{|c|}{ Annual population growth rate (\%) statistics for the study area } \\
\hline & $1960-1970$ & $1970-1984$ & $1984-2000$ & $2000-2010$ & $2010-2020$ & $1960-2020$ \\
\hline Southwestern Ghana & 2.1 & 3.0 & 3.2 & 2.0 & 3.0 & 6.5 \\
\hline
\end{tabular}


Table 7

Summary of existing literature on policy-driven factors, major events, and LULD studies in Southwestern Ghana (1970-2020)

\begin{tabular}{|c|c|c|c|c|}
\hline Periods & Driving factors & Consequences & Transitions & Source (Literature) \\
\hline 1970s & Agricultural expansion (proximate cause). & $\begin{array}{l}\text { Increase in small-scale } \\
\text { subsistent farming } \\
\text { (farmlands \& shrubs) } \\
\text { resulting in marginal } \\
\text { deterioration of natural } \\
\text { forests (pristine } \\
\text { environment). }\end{array}$ & $\begin{array}{l}\text { Bare land and forest lands } \\
\text { to farmlands and shrubs, } \\
\text { small-scale farms as well } \\
\text { as settlements. }\end{array}$ & $\begin{array}{l}\text { Gockowski and } \\
\text { Sonwa 2011; } \\
\text { Dickson and Benneh } \\
\text { 1988; Hall and } \\
\text { Swaine 1976; Ahn } \\
1958\end{array}$ \\
\hline $\begin{array}{l}\text { 1970s- } \\
\text { 1980s }\end{array}$ & $\begin{array}{l}\text { Population growth and distribution (Underlying cause). } \\
\text { Agricultural expansion (proximate cause). }\end{array}$ & $\begin{array}{l}\text { Increase in human } \\
\text { settlements. } \\
\text { Increase in small-scale } \\
\text { subsistent farming } \\
\text { (farmlands \& shrubs) } \\
\text { resulting in marginal } \\
\text { alteration of natural } \\
\text { forests (pristine } \\
\text { environment). }\end{array}$ & $\begin{array}{l}\text { Bare land and forest lands } \\
\text { to farmlands and shrubs, } \\
\text { subsistent/medium-scale } \\
\text { farms }\end{array}$ & $\begin{array}{l}\text { Damnyag et al. } \\
\text { 2017; Gyasi et. al } \\
\text { 1994; Brooke 1989; } \\
\text { Arhin 1985; Hall and } \\
\text { Swaine 1976. }\end{array}$ \\
\hline $\begin{array}{l}\text { 1980s- } \\
1990 \mathrm{~s}\end{array}$ & $\begin{array}{l}\text { Biophysical and climatic factors (i.e., Droughts (1981-1983), } \\
\text { Famine, bushfires and higher temperatures) (proximate } \\
\text { cause) } \\
\text { Economic (Macro-economic Reforms), Socio-political } \\
\text { (Policy) and institutional factors (i.e., } 1983 \text { (GoG) Economic } \\
\text { Recovery Program with support from IMF/World Bank, land } \\
\text { tenure systems) } \\
\text { (Underlying cause). }\end{array}$ & $\begin{array}{l}\text { Spontaneous } \\
\text { immigration and forced } \\
\text { settlements from other } \\
\text { regions and increase in } \\
\text { population led to } \\
\text { reduction in natural } \\
\text { forests and significant } \\
\text { increase in bare land, } \\
\text { farmlands and shrubs } \\
\text { (Table 4). } \\
\text { Loss of biodiversity and } \\
\text { health problems. } \\
\text { Increasing temperatures } \\
\text { (dry climate) and } \\
\text { reduced rainfall. } \\
\text { Redistribution of lands } \\
\text { and conversion of } \\
\text { natural forests to } \\
\text { farmlands. The state and } \\
\text { individuals emerged as } \\
\text { dominant economic } \\
\text { agents in the economy. }\end{array}$ & $\begin{array}{l}\text { Forest lands converted to } \\
\text { farmlands and shrubs, } \\
\text { bare land and human } \\
\text { settlements. }\end{array}$ & $\begin{array}{l}\text { Tan and Rockmore } \\
\text { 2018; Huq and Tribe } \\
\text { 2018; Abbam et al. } \\
\text { 2018; Nikoi 2015; } \\
\text { Aryeetey and Kabur } \\
\text { 2008; Gyasi et. al } \\
\text { 1994; Kusi 1991; } \\
\text { Brooke 1989; Dei } \\
\text { 1988. }\end{array}$ \\
\hline $\begin{array}{l}1990 s- \\
2000\end{array}$ & $\begin{array}{l}\text { Socio-economic development (i.e., Policies driven towards } \\
\text { Ghana's Vision 2020, poverty reduction (i.e., Core Welfare } \\
\text { Indicators Questionnaire (CWIQ) and the Ghana Living } \\
\text { Standards Survey (GLSS), improvement in Human } \\
\text { Development Indicators (HDIs), export led agricultural } \\
\text { production and expansion in foreign investment) } \\
\text { (Underlying causes). } \\
\text { Population pressure (underlying cause). } \\
\text { Biophysical and climatic factors (i.e., temperature rise) } \\
\text { (Proximate cause). }\end{array}$ & $\begin{array}{l}\text { Development of } \\
\text { infrastructure such as } \\
\text { transportation networks, } \\
\text { education and health } \\
\text { facilities. } \\
\text { Domestic and foreign } \\
\text { investment in farming } \\
\text { activities. } \\
\text { Population growth and } \\
\text { significant increase in } \\
\text { human settlements. High } \\
\text { rate of deforestation. } \\
\text { Need to meet food } \\
\text { demands led to an } \\
\text { increase in the rate of } \\
\text { farming activities. } \\
\text { Increase in surface } \\
\text { temperatures and } \\
\text { reduced precipitation } \\
\text { (Table } 4 \text { and Fig. 5) due } \\
\text { to significant increase in } \\
\text { built-up environment. } \\
\text { Loss of biodiversity and } \\
\text { health problems. }\end{array}$ & $\begin{array}{l}\text { Forests, bare land, } \\
\text { farmlands and shrubs } \\
\text { converted to } \\
\text { settlements/infrastructure, } \\
\text { subsistent and } \\
\text { medium/large scale farms }\end{array}$ & $\begin{array}{l}\text { Huq and Tribe 2018; } \\
\text { Abbam et al. 2018; } \\
\text { Damnyag et al. } \\
\text { 2017; Koranteng and } \\
\text { Zawila-Niedzwieki } \\
\text { 2016; Noponen et al. } \\
\text { 2014; Gockowski } \\
\text { and Sonwa 2011; } \\
\text { Kusimi 2008; Gyasi } \\
\text { et al. 1994; Kusi } \\
\text { 1991. }\end{array}$ \\
\hline
\end{tabular}




\begin{tabular}{|c|c|c|c|c|}
\hline Periods & Driving factors & Consequences & Transitions & Source (Literature) \\
\hline $\begin{array}{l}2000- \\
2010\end{array}$ & $\begin{array}{l}\text { Adoption of new governance systems (i.e., Adoption of } \\
\text { capitalism and free-market (liberalists) (Underlying cause). } \\
\text { Rapid population growth (Underlying cause) } \\
\text { Economic Reforms led to the application for enhanced } \\
\text { Highly Indebted Poor Country (HIPC) in 2001, Ghana Poverty } \\
\text { Reduction Strategy I (2003-2005) \& II. Implementation of } \\
\text { sectoral policies designed to promote Sustainable Economic } \\
\text { Growth and high incidence of poverty in Ghana. } \\
\text { Interventions like the School Feeding Program, } \\
\text { NYEP/GYEEDA, LEAP, NHIS). }\end{array}$ & $\begin{array}{l}\text { High rate of } \\
\text { deforestation. } \\
\text { Increasing rate of } \\
\text { settlements and } \\
\text { infrastructure. } \\
\text { Increase in surface } \\
\text { temperatures and a } \\
\text { decline in rainfall. } \\
\text { Decline in farming } \\
\text { activities (Table 4). }\end{array}$ & $\begin{array}{l}\text { Farmlands and shrubs, } \\
\text { bare land, and forests } \\
\text { converted to settlements } \\
\text { and infrastructure. }\end{array}$ & $\begin{array}{l}\text { Mensah et al. 2019; } \\
\text { Acheampong et al. } \\
\text { 2018; Huq and Tribe } \\
\text { 2018; Abbam et al. } \\
\text { 2018; Damnyag et. } \\
\text { al 2017; Aduah and } \\
\text { Baffoe 2013; Aduah } \\
\text { et. al 2012; } \\
\text { Gockowski and } \\
\text { Sonwa 2011; Kusimi } \\
\text { 2008; Aryeetey and } \\
\text { Kabur 2008. }\end{array}$ \\
\hline $\begin{array}{l}2010- \\
2020\end{array}$ & $\begin{array}{l}\text { Population growth and distribution (Underlying cause) } \\
\text { Tree plantation (Afforestation) (i.e., GYEEDA, Carbon } \\
\text { Sequestration Development Project, REDD+ Hotspot } \\
\text { Strategy, planting for food and jobs). } \\
\text { Infrastructural Development (2010-2016) (i.e., Community } \\
\text { Day schools, district and regional hospitals, Roads and } \\
\text { railway networks, Storage Facilities-Warehouses, Housing } \\
\text { units among others) (proximate cause). } \\
\text { Economic policies driven towards Industrialization and } \\
\text { fiscal discipline (Macro and micro economic stability) (i.e., } \\
\text { One-district-one factory, reducing Balance of Payment } \\
\text { deficits (BoP) and so on. Increase in the prices of some } \\
\text { agricultural commodities (i.e., increase in cashew, timber, } \\
\text { cocoa producer prices). Encouraging domestic and foreign } \\
\text { investors to venture into agriculture and other natural } \\
\text { resource or profit-oriented sectors (Underlying cause). }\end{array}$ & $\begin{array}{l}\text { Expansion of } \\
\text { settlements and } \\
\text { infrastructure. } \\
\text { High rate of } \\
\text { deforestation. } \\
\text { Increase in surface } \\
\text { temperature and decline } \\
\text { in rainfall. } \\
\text { Expansion of cultivated } \\
\text { lands done on small, } \\
\text { medium and large scale } \\
\text { to boost exports and } \\
\text { provide more raw } \\
\text { materials for industries. } \\
\text { Efforts channeled } \\
\text { towards profit-oriented } \\
\text { sectors (i.e., natural } \\
\text { resources) have resulted } \\
\text { in a decline of other } \\
\text { sectors. }\end{array}$ & $\begin{array}{l}\text { Forests and bare land } \\
\text { converted to human } \\
\text { settlements and } \\
\text { farmlands. }\end{array}$ & $\begin{array}{l}\text { Mensah et al. 2019; } \\
\text { Geiger et al. 2019; } \\
\text { Acheampong et al. } \\
\text { 2018; Huq and Tribe } \\
\text { 2018; Abbam et al. } \\
\text { 2018; Damnyag et. } \\
\text { al 2017; Kleemann } \\
\text { et. al 2017; } \\
\text { Koranteng et } \\
\text { al.2017; Noponen et. } \\
\text { al 2014; Aduah and } \\
\text { Baffoe 2013; Aduah } \\
\text { et. al 2012; Logah et. } \\
\text { al 2011. }\end{array}$ \\
\hline
\end{tabular}

Table 8: Description of experts' rank on most influential drivers of LULD in Southwestern Ghana

\begin{tabular}{|c|c|c|c|}
\hline Driving Factors & Tally/Rank & $\begin{array}{l}\text { Frequency } \\
\left(\begin{array}{l}\mathrm{N}=22) \\
(\%)\end{array}\right.\end{array}$ & Position \\
\hline $\begin{array}{l}\text { Expansion in settlements \& social infrastructure: Schools, health facilities, transportation networks, } \\
\text { housing/real estates, Market and storage facilities, drainage systems and so on). }\end{array}$ & $\sqrt{ } \sqrt{ } \sqrt{ }$ & $6(28 \%)$ & $2^{\text {nd }}$ \\
\hline $\begin{array}{l}\text { b. Economic factors: Population growth and distribution, micro/macro-economic factors, Mining, illegal } \\
\text { logging, incentives/subsidies and so on, market forces/prices, price of commodities on domestic and international } \\
\text { market, promoting exports/balance of payment deficit and so on. }\end{array}$ & $\sqrt{ } \sqrt{ } \sqrt{ } \sqrt{ }$ & $8(36 \%)$ & $1^{\text {st }}$ \\
\hline $\begin{array}{l}\text { c. Political factors: state policies that promote farming and deforestation and land degradation, weak } \\
\text { governance systems, institutional frameworks, land tenure systems, monitoring and enforcement of regulations. }\end{array}$ & $\sqrt{ } \sqrt{ } \sqrt{ }$ & $4(18 \%)$ & $3^{\text {rd }}$ \\
\hline $\begin{array}{l}\text { d. Agricultural activities \& Technological factors: agro-technical input and efficiency, mining technology, } \\
\text { transportation networks) }\end{array}$ & $\sqrt{ } \sqrt{ }$ & $2(9 \%)$ & $4^{\text {th }}$ \\
\hline $\begin{array}{l}\text { e. Natural or biophysical factors: Increase in temperature, droughts, wildfires, flooding, fluctuations in rainfall, } \\
\text { topography, aspect, slope and so on }\end{array}$ & $\sqrt{ }$ & $2(9 \%)$ & $5^{\text {th }}$ \\
\hline
\end{tabular}

Respondents' assertion of some key driving forces influencing LULD IN SW Ghana. The rank (Table 8) among other key parameters highlights the most/least influential factors resulting in substantial LULD over the past five decades.

Table 9

Confidence level analysis using the MMA to ascertain local drivers of LULD 


\begin{tabular}{|c|c|c|c|c|c|}
\hline \multirow[t]{2}{*}{$\begin{array}{l}\text { Scope: } \\
\text { Drivers of LULD }\end{array}$} & \multirow[t]{2}{*}{ Keywords } & $\begin{array}{l}\text { Literature } \\
\text { Review }\end{array}$ & Interviews & $\begin{array}{l}\text { Spatial } \\
\text { Analysis }\end{array}$ & $\begin{array}{l}\text { Confidence } \\
\text { level }\end{array}$ \\
\hline & & SW Ghana & $\begin{array}{l}\text { SW } \\
\text { Ghana }\end{array}$ & SW Ghana & SW Ghana \\
\hline \multirow{9}{*}{$\begin{array}{l}\text { Proximate } \\
\text { Causes }\end{array}$} & Settlements & $\sqrt{\sqrt{ } \sqrt{ }}$ & $\sqrt{\sqrt{ } \sqrt{ }}$ & $\sqrt{\sqrt{ } \sqrt{ }}$ & Very High \\
\hline & Wood extraction & $\sqrt{\sqrt{ }}$ & $\sqrt{ } \sqrt{ }$ & $\sqrt{ }$ & Medium \\
\hline & Mining \& Infrastructure & $\sqrt{\sqrt{ } \sqrt{ }}$ & $\sqrt{\sqrt{ } \sqrt{ }}$ & $\sqrt{\sqrt{ } \sqrt{ }}$ & Very High \\
\hline & Agriculture expansion & $\overline{\sqrt{ } \sqrt{ }}$ & $\sqrt{\sqrt{ }}$ & $\overline{\sqrt{ } \sqrt{ }}$ & High \\
\hline & Bushfires/Wildfires & $\sqrt{ }$ & $\sqrt{ }$ & $\mathrm{X}$ & Low \\
\hline & Famine & $\sqrt{\sqrt{ } \sqrt{ }}$ & $\sqrt{ }$ & $\mathrm{X}$ & Medium \\
\hline & High temperature & $\sqrt{\sqrt{ } \sqrt{ }}$ & $\sqrt{\sqrt{ } \sqrt{ }}$ & $\sqrt{\sqrt{ } \sqrt{ }}$ & Very High \\
\hline & Floods & $\sqrt{\sqrt{ }}$ & $\sqrt{\sqrt{ }}$ & $\mathrm{X}$ & Medium \\
\hline & Soil Quality & $\mathrm{X}$ & $\sqrt{ }$ & $\mathrm{X}$ & Very Low \\
\hline \multirow{6}{*}{$\begin{array}{l}\text { Underlying } \\
\text { Causes }\end{array}$} & & & & & \\
\hline & Poverty & $\sqrt{\sqrt{ } \sqrt{ }}$ & $\sqrt{\sqrt{ } \sqrt{ }}$ & $\mathrm{X}$ & High \\
\hline & Population growth and distribution & $\sqrt{\sqrt{ } \sqrt{ }}$ & $\sqrt{\sqrt{ } \sqrt{ }}$ & $\sqrt{\sqrt{ } \sqrt{ }}$ & Very High \\
\hline & Weak governance, Monitoring and Enforcement mechanisms & $\sqrt{ } \sqrt{ }$ & $\sqrt{ } \sqrt{ }$ & $\mathrm{X}$ & Medium \\
\hline & $\begin{array}{c}\text { Technology (Science, research, mining technology, agro-technical change and efficiency, transportation } \\
\text { networks) }\end{array}$ & $\sqrt{ } \sqrt{ }$ & $\sqrt{ } \sqrt{ }$ & $\mathrm{X}$ & Medium \\
\hline & Cultural values, behaviour and beliefs & $\sqrt{ } \sqrt{ }$ & $\sqrt{ } \sqrt{ }$ & $\mathrm{X}$ & Medium \\
\hline \multirow[t]{2}{*}{$\begin{array}{l}\text { Effects on some climatic } \\
\text { variables }\end{array}$} & Increasing temperature & $\sqrt{\sqrt{ } \sqrt{ }}$ & $\sqrt{\sqrt{ } \sqrt{ }}$ & $\sqrt{\sqrt{ } \sqrt{ }}$ & Very High \\
\hline & Unpredictable/Fluctuations in rainfall patterns & $\sqrt{ } \sqrt{ }$ & $\sqrt{ } \sqrt{ }$ & $\mathrm{X}$ & High \\
\hline
\end{tabular}

\subsection{Interpretation of results based on AHP}

The risk factors stated in this study comprised biophysical (natural) and proximate/underlying drivers that influence LUCC in Southwestern Ghana (Tables 10). The pair-wise matrices were normalized, along with their generated level of consistencies. The value of consistency ratio (CR) of the drivers on the pairwise matrix is 0.01 . This indicates the outlined drivers in the pair-wise matrix is reasonably consistent. High Temperature (HT) is given $30.88 \%$ weight representing the highest ranked biophysical driver and in descending order of severity; Bushfires/Wildfires (BFW) having 22.62\% weight; Unpredicted/Fluctuations in rainfall patterns (UFRP) given $17.80 \%$ weighting; Floods (FI) and Famine (F) assigned $11.16 \%$ weighting respectively,whereas soil quality (SQ) obtained $6.37 \%$ weighting. 
Table 10

Measuring consistency of biophysical and proximate/underlying drivers

\begin{tabular}{|c|c|c|c|c|c|c|c|c|c|c|c|}
\hline & D & $\mathrm{s}$ & WE & SPOI & MI & $\mathrm{AE}$ & $M$ & $P$ & PGD & WGMEM & $\mathrm{T}$ \\
\hline D & 0.129 & 0.129 & 0.124 & 0.124 & 0.129 & 0.147 & 0.129 & 0.147 & 0.129 & 0.124 & 0.124 \\
\hline S & 0.129 & 0.129 & 0.124 & 0.124 & 0.129 & 0.147 & 0.129 & 0.147 & 0.129 & 0.124 & 0.124 \\
\hline WE & 0.043 & 0.043 & 0.041 & 0.041 & 0.043 & 0.037 & 0.043 & 0.037 & 0.043 & 0.041 & 0.041 \\
\hline SPOI & 0.043 & 0.043 & 0.041 & 0.041 & 0.043 & 0.037 & 0.043 & 0.037 & 0.043 & 0.041 & 0.041 \\
\hline MI & 0.129 & 0.129 & 0.124 & 0.124 & 0.129 & 0.147 & 0.129 & 0.147 & 0.129 & 0.124 & 0.124 \\
\hline $\mathrm{AE}$ & 0.065 & 0.065 & 0.082 & 0.082 & 0.065 & 0.073 & 0.065 & 0.073 & 0.065 & 0.082 & 0.082 \\
\hline M & 0.129 & 0.129 & 0.124 & 0.124 & 0.129 & 0.147 & 0.129 & 0.147 & 0.129 & 0.124 & 0.124 \\
\hline$P$ & 0.065 & 0.065 & 0.082 & 0.082 & 0.065 & 0.147 & 0.065 & 0.073 & 0.065 & 0.082 & 0.082 \\
\hline PGD & 0.129 & 0.129 & 0.124 & 0.124 & 0.129 & 0.147 & 0.129 & 0.147 & 0.129 & 0.124 & 0.124 \\
\hline WGMEM & 0.043 & 0.043 & 0.041 & 0.041 & 0.043 & 0.037 & 0.043 & 0.037 & 0.043 & 0.041 & 0.041 \\
\hline$T$ & 0.043 & 0.043 & 0.041 & 0.041 & 0.043 & 0.037 & 0.043 & 0.037 & 0.043 & 0.041 & 0.041 \\
\hline CVBB & 0.043 & 0.043 & 0.041 & 0.041 & 0.043 & 0.037 & 0.043 & 0.037 & 0.043 & 0.041 & 0.041 \\
\hline \multicolumn{12}{|c|}{ Measuring consistency of biophysical drivers } \\
\hline \multirow[t]{2}{*}{ CW } & 0.1116 & 0.3088 & 0.1116 & 0.0637 & 0.2262 & 0.178 & & & & & \\
\hline & $\mathbf{F}$ & $\mathrm{HT}$ & FI & SQ & BFW & UFRP & WSV & WSV/CW & $\lambda \max$ & $\mathrm{Cl}$ & CR \\
\hline $\mathbf{F}$ & 0.1116 & 0.1029 & 0.1116 & 0.1910 & 0.0754 & 0.0890 & 0.6816 & 6.1063 & & & \\
\hline HT & 0.3349 & 0.3088 & 0.3349 & 0.3184 & 0.2262 & 0.3560 & 1.8792 & 6.0850 & & & \\
\hline FI & 0.1116 & 0.1029 & 0.1116 & 0.1910 & 0.0754 & 0.0890 & 0.6816 & 6.1063 & 6.0763 & 0.0153 & 0.01 \\
\hline SQ & 0.0372 & 0.0618 & 0.0372 & 0.0637 & 0.1131 & 0.0593 & 0.3723 & 5.8472 & & & \\
\hline BFW & 0.0558 & 0.3088 & 0.3349 & 0.1273 & 0.2262 & 0.3560 & 1.4091 & 6.2289 & & & \\
\hline UFRP & 0.2233 & 0.1544 & 0.2233 & 0.1910 & 0.1131 & 0.1780 & 1.0831 & 6.0841 & & & \\
\hline
\end{tabular}

Again, consistency for the given parameters that drive land degradation and land cover change entailed Deforestation (D), Settlements (S)

Mining/infrastructure (MI); Migration (M) and Population Growth and Distribution (PGD) are given 12.94\% respectively; Agriculture Expansion (AE) and Poverty (P) again received 7.34\% weightings; Wood Extraction (WE) and Setting up Profit Oriented Industries (SPOI) obtained $4.12 \%$ weightings while Technology (T); Weak Governance, Monitoring \& Enforcement Mechanisms (WGMEM) and Cultural Values, Behaviours and Beliefs (CVBB) received 4.12\% weightings. Findings based on $\mathrm{CR}$ and $\mathrm{Cl}$ show experts' judgements are pragmatic. Hence, results generated from the expert interviews can be used to validate findings from existing literature and spatial analysis.

\subsection{Temperature Analysis}

Figure 9 indicates temperature range on average was between $27.78^{\circ} \mathrm{C}$ and $20.23^{\circ} \mathrm{C}$ in the 1970 s. However, the average temperature range for 1980 s was between $30.44^{\circ} \mathrm{C}$ and $27.78^{\circ} \mathrm{C}$, which could be attributed to biophysical factors (i.e., bushfires and prolonged dryness that occurred in the 1980 s), which caused significant increase in surface temperatures in the study area. The range for the 1990 s was between $28.88^{\circ} \mathrm{C}$ and $25.45^{\circ} \mathrm{C}$. Average temperature range for 2000,2010 and 2020 were between $30.12^{\circ} \mathrm{C}$ and $23.67^{\circ} \mathrm{C}, 31.66^{\circ} \mathrm{C}$ and $24.44^{\circ} \mathrm{C}$, as well as $33.76^{\circ} \mathrm{C}$ and $24.54^{\circ} \mathrm{C}$, respectively. Dark red and yellowish areas indicate areas with high or moderately high temperatures whilst dark blue areas represent low temperature regions with transient colour zones.

\section{Discussion}

\subsection{Land use cover change in Southwestern Ghana}

Per the conversions in various land cover types observed in Fig. 6-7 and Fig. 10-11, there is evidence of expansion in farmlands/shrubs and built-up areas over the given period. Additionally, previous studies, policy-driven initiatives and experts' assertion highlighted in Tables 7-8 respectively, illustrate recurrent changes in the study area. Findings based on geo-statistical analysis illustrated drastic increase in farmlands/shrubs (+369.81\%) and built-up areas (+1288.36\%) at the expense of a reduction in forested areas (-82\%), waterbodies $(-27 \%)$ and bare land $(-18.06)$. Conversely, $73 \%$ of experts asserted that there has a decline in forest areas in Southwestern Ghana over the past 50 years. Results agree with the standpoints of Kusimi (2008), Damnyag et al. (2017), Kleemann et al. (2017), Acheampong et al. (2018) and Mensah et al. (2019), who attributed loss of forests areas over the past few decades to several socio-economic factors namely; rapid urbanization, population growth and distribution, influx of profit-oriented industries, agriculture and infrastructure expansion. 


\subsubsection{Contribution rate of change for the various indices (1970-2020) in Southwestern Ghana}

The estimated NDVI range for the 1970 s was between -0.96 and 1 . The range for 1980 s was between -0.97 and 0.79 . The 1990 s had a range of -0.93 and 0.81 ; 2000 s had a range of -0.85 and $0.75 ; 2010$ ranged between -0.87 and 0.70 , and 2020 depicted an NDVI range of -0.90 and 0.64 . Fig. 10 illustrates a steady decline in vegetative index over the study period. Larger values of NDVI represent forest areas due to higher green biomass of trees and other vegetation. These areas as observed over the study period (1970-2020) constitute mainly forest and wildlife reserves/parks, closed (dense) and open canopies. Decrease in NDVI based on study findings could be attributed to the main drivers highlighted in Table 7. Differences in measurement of vegetation in Southwestern Ghana was visualized in image differencing using NDVI over the given study periods. Areas marked with violet (Fig. 10) represent a highly negative change, thus, major reduction in vegetation cover as observed in the 1970s and 1980s. Such areas as depicted in Fig. 10 are subdued by the sea or built-up environment. Yellowish and greenish areas indicate areas with moderate and dense vegetation cover, respectively with an increasing rate of agricultural areas (between 2000 and 2020).

Figure 11 illustrates changes in NDBI over the study period in Southwestern Ghana. It is observed that NDBI ranged between -0.80 and 0.29 for the 1970 s. The 1980 s had an NDBI range between -0.77 and 0.37 , and -0.75 to 0.49 for the 1990 s. Again, the NDBI range for the 2000 s was between -0.70 and 0.62 . A significant increment was observed in 2010 when NDBI ranged between -0.85 and 0.77 ; NDBI range for 2020 was between -0.83 and 0.79 . There is clear evidence of continuous expansion of settlements over the study period in the study area. Differences in measurement of built-up areas in Southwestern Ghana was visualized in image differencing using NDBI over the given study period. Dark red and yellowish areas indicate high presence of built-up environment. Light green and green areas represent areas covered by farmlands and shrubs as well as less dense vegetation. Dark blue areas represent areas covered by forest and wildlife reserves (deciduous and semi-deciduous zones) or water bodies as shown in Figure 11.

Given the results in Fig. 10 and Fig. 11, along with the contribution rate of change for the various classes among the given indices presented in Table 6, it is evident that built-up areas contributed the most to changes among other classes in NDBI (9.00) and NDVI (6.20), followed by farmlands/shrubs ( 0.33 and 0.54 in relation to the respective indices) with a decline in area coverage for the other classes over the given study period. Results presented in Table 6 shows continuous increase in built-up in the distribution for CRC depicted in Table 6 \& Fig. 9 (LST) revealed a positive or direct relationship between built-up and LST.

\subsection{Identified drivers of LUCC based on Confidence level results}

In this study, results from LUCC analysis (Table 6), early studies (Table 7) and expert interviews revealed substantial increase in built-up areas. Geospatial analysis (Fig. 7 and Fig. 11) and observations in Table 9 shows built-up class (+1288.36\%) was the highest contributor of change over the last 50 years among other classes. These undesirable and unprecedented changes are associated population growth, high rate of deforestation as a result of increasing settlements, LSM/ASM activities and development of socio-economic infrastructure, could influence long term consequences linked to land/soil degradation and climate variability. The distribution (Table 6) according to GSS (2020) shows an increase in population growth rate between 1960-1984 (2.1-3.2\%), followed by a decline in 2000-2010 (2\%). The area has experienced an annual growth rate of $6.5 \%$ (1960-2020), thereby validating experts' judgements and results from geospatial analysis conducted. Respondents affirmed there had been a remarkable increase in human population over the past 50 years. The rapid growth in population based on GSS (2020), Moller-Jensen and Knudsen (2008) and experts interviewed were attributed to migration of people from nearby regions and border towns of neighbouring countries. $53 \%$ asserted migration was the main cause of increasing population in the region, while $13 \%$ revealed high birth rate as the cause; with $33 \%$ attributing the reason to both migration and high birth rate. Studies highlighted above revealed people migrated to Southwestern Ghana for greener pastures. Common activities in the area include LSM/ASM, fisheries/agriculture and construction. Moller-Jensen and Knudsen (2008) and Owusu-Nimo et.al (2018) revealed population growth exacerbated pressure on land, minerals and forest resources in the region. Hence, the conversion of forests, bare land and areas covered by waterbodies into built-up (Fig. 7). Competing needs among relevant stakeholders have resulted in several unintended consequences, driving land and forest degradation through farming activities to boost exports, illegal logging of trees and chain sawing of timber plantations, coupled with LSM/ASM activities without prudent post-mining reclamation plans.

Considering the outcome presented in Table 9, it is evident that there is robust evidence and high agreement between the three methods. Spatial results (Fig. 78 and Fig. 10-11) present the contribution rates of various classes or indices (NDBI and NDVI) towards transitions and land or forest degradation. It can clearly be stated that there is "very high confidence" in the aforementioned drivers identified in this study. Results proved these economic driving forces causing unprecedented changes in the region are influenced by some macro and micro-economic factors, primarily state policies, aimed towards poverty alleviation or improving living standards, as presented in Table 7. Intensification and extensification of agricultural activities (Table 9) (Fig. 6 and Fig. 7) in the area over the study period have been linked to the citizenry resorting to use of traditional and reserved lands/forest reserves (encroaching protected areas) among other natural resources as the last means of employment. Damnyag et al. (2017) and Noponen et al. (2014) revealed increase in producer price of some commodities like cocoa on the international and domestic markets in recent times motivated most locals to venture into farming. This has resulted in cash cropping regimes, influencing land cover change in the area as several forests are cleared and burnt. Among the major crops cultivated in the area as revealed by experts and existing literature (Damnyag et al. 2017; Noponen et al. 2014) constitute cocoa, rubber, plantain, cassava and cocoyam. However, unfavourable climatic conditions coupled with rapid increase in LSM/ASM activities commonly known in local terms as "Galamsey (connotes gather and sell)", have propelled most of the youth to venture into mining instead of agriculture today. These factors have rendered most lands and soils unproductive.

Moreover, geospatial analysis presented in Fig. 6 and Fig. 7 between 1980 and 2000 presents significant changes through a reduction in areas covered by natural forests, and a substantial increase in farmlands/shrubs and built-up areas. Ghana in the early 1980 s, specifically 1983 experienced famine along with recorded incidents of wildfires which claimed several forests and farmlands, thereby influencing prevailing micro-climatic conditions, specifically temperature (Fig. 9). Post-famine period saw the formulation and effective implementation of an "Economic Recovery and Stabilization Program (ERP) in 1983" that

Page 15/35 
boosted agriculture with the intention of enhancing food production and improving living standards. Provision of basic amenities and construction of quality transportation networks was intensified. These policies within the said period caused several conversions and modification of several land cover types.

Despite the amplitude of several structural transformation programs to change Ghana's economy (2000-2020) from a raw to a manufacturing/industrialized economy, the country's commitment to achieve the SDGs 1, 2, 13 and 15 in recent years have significantly altered land use processes and prevailing microclimatic conditions in the region (Table 7) (Fig. 7) (Abbam et al. 2018; Aduah and Baffoe, 2013; Aduah et al. 2012; Logah et al. 2011). It was during the 19802000 era that natural factors significantly influenced these modifications. From the lens of the pessimists, despite increasing temperature and recorded incidents of flood events in recent periods (Abbam et al. 2018; Damnyag et al. 2017), major events like prolonged dryness, wildfires, among others, degraded most lands and rendered most areas unproductive. Extensiveness of agricultural activities (Fig. 6) (Table 8) due to massive clearing of forest areas, coupled with slash and burn have exposed several top-soils to wild fires, thereby reducing their fertility. These have partly accounted for the decline in cocoa and other cash crops productivity in recent years. Ghana recorded 1 million tonnes of cocoa production in 2012, with two-thirds of this production evolving from Southwestern Ghana. In recent years, cocoa production in the area has been declining mainly as a result of these drivers causing modifications and land degradation. Results from the table of confidence (Table 9) exhibited "very high-to-very low confidence" in some biophysical factors like temperature, bushfires, floods and soil quality, respectively. The distribution shows there was limited evidence provided by at least one method. Hence, providing "very highto-very low confidence" for most direct and indirect drivers identified using the three (3) methods. There was however no spatial information on other natural factors other than temperature (Fig. 9), which may partly influence confidence in results despite expert interviews and existing studies presenting evidence and agreement levels. With "very high confidence" changes in temperature based on spatial analysis, expert interviews and literature review (Table 7) (Table 9) (Abbam et al. 2018; Aduah and Baffoe 2013; Aduah et al. 2012) show temperature as a climatic variable with spatiotemporal attributes are capable of driving land cover change and land degradation. In the same vein, there was agreement in results from the expert interviews and existing literature, in relation to other contributory factors like institutional/political (governance structures, monitoring and enforcement mechanisms), technology (science and research, agroforestry, climate-smart agriculture, mining operations, transportation networks and technical efficiency) as well as cultural and behavioural (lifestyle, beliefs, traditions and perception) factors. Evidence from these two methods, coupled with the level of agreement between them proved there is "medium confidence" in the drivers identified. This eventually shows evidence provided to ascertain major influences of LULD are valid and reliable based on the qualitative and quantitative strategies used.

Damnyag et al. (2017) reported that political and technological factors could sooner or later become dominant drivers from the pessimist and optimist perspective. They attributed reasons to current trends and advocacy for intensive scientific research and innovation to enhance productivity aimed at meeting global demands. We considered technological, cultural and behavioural factors which are often overlooked or deemed irrelevant in LULD studies as drivers that could be further analysed and addressed against the unknown. Based on the aforementioned reasons, it is becoming increasingly evident that biophysical (emanating from climate disturbances/stressors), cultural and technological factors that had "medium-to-very low confidence" (Table 9) could potentially influence food security, land/water resources and livelihoods in the near future. Therefore, these parameters cannot be overlooked since in the distant future, they could be dominant in causing significant changes to land cover systems and forest resources.

Table 11 presents the strengths and limitations of individual methods that could affect the validity and reliability of study findings. Consequently, the adoption of MMA for analysing the main drivers of land cover change and land degradation provides the needed platform for comparative studies. In the present study, we demonstrated that a combination of expert interviews, literature review and spatial analysis can be used to assess and improve confidence in results. Expert interviews and AHP through the use of questionnaires, were used to bridge paucity of information in existing literature and spatial analysis. Geospatial analysis provided vivid details of changes on the ground (Rindfuss and Stern 1998). This complements the limitation of subjectivity in the other two qualitative research strategies. Again, results from most qualitative research strategies are often regarded as less reliable based on several discretionary factors (Haradhan 2018; Queirós et al. 2017). Weight of importance are given to outcomes generated by quantitative tools. Qualitative methods used in this study aim at deepening our understanding on factors that cannot be quantified with high rate of flexibility and exploratory analysis (Haradhan 2018; Queirós et al. 2017). The AHP was used to assign weights to expert judgements, thereby ensuring consistency or accuracy in findings to limit subjectivity. Contextually, satellite imagery is limited in identifying indirect/underlying factors that drive LULD. Here, we resorted to merge both strategies (Table 9), adhering to the strengths of these methods and restricting the limitations in the use of these methods to ensure "high confidence" in findings. 
Table 11

Strengths and limitations of various methods used in our study

\begin{tabular}{|c|c|c|}
\hline Method & Strengths & Limitations \\
\hline \multirow{3}{*}{$\begin{array}{l}\text { Summary } \\
\text { of } \\
\text { Literature }\end{array}$} & $\begin{array}{l}\text {-Entails thematic areas that cover the overall scope of this study and studies } \\
\text { linked to land use/ climate variability. }\end{array}$ & $\begin{array}{l}\text {-Most studies on Land use conducted in SW Ghana are } \\
\text { limited to small areas with limited scope. }\end{array}$ \\
\hline & \multirow{2}{*}{$\begin{array}{l}\text { - This approach was used to describe land use studies and methodologies, } \\
\text { carried out in the study area. Studies used either support (build) or reject } \\
\text { existing knowledge/propositions. }\end{array}$} & $\begin{array}{l}\text {-Approaches used in most of the studies differ from one } \\
\text { another. }\end{array}$ \\
\hline & & $\begin{array}{l}\text {-May have overlooked some other relevant studies which } \\
\text { are not found in most common journals or institutional } \\
\text { platforms and databases. }\end{array}$ \\
\hline \multirow[t]{6}{*}{$\begin{array}{l}\text { Expert } \\
\text { Interviews }\end{array}$} & $\begin{array}{l}\text {-Using semi-structured questionnaires, primarily focused on major influences } \\
\text { in SW Ghana that drive LUCC. It was employed as an approach to validate } \\
\text { results from the other two-methods used. }\end{array}$ & \multirow{2}{*}{$\begin{array}{l}\text {-Cultural and behavioural concerns mainly due to the } \\
\text { pandemic (COVID-19). } \\
\text {-Definition of experts as stipulated in this study may be } \\
\text { relative/discretional. }\end{array}$} \\
\hline & \multirow{3}{*}{$\begin{array}{l}\text {-Provided information about both indirect/underlying (non-spatial) factors } \\
\text { that influenced LUCC to bridge knowledge gaps in the other methods and } \\
\text { deepen our understanding about the subject matter. } \\
\text {-Scientific background and professional capacity of experts made it feasible } \\
\text { and easy to filter irrelevant information based on inputs given. }\end{array}$} & \\
\hline & & \multirow{4}{*}{$\begin{array}{l}\text {-Despite most interviewees having technical \& social } \\
\text { science backgrounds, some other drivers which may be } \\
\text { known to some other knowledge groups might have been } \\
\text { omitted/overlooked. }\end{array}$} \\
\hline & & \\
\hline & $\begin{array}{l}\text {-Concept of "think globally" and "act locally" is adhered to considering land } \\
\text { use being considered as a mesoscale element and driver of global } \\
\text { climate/environmental change. This approach has a high rate of flexibility } \\
\text { and exploratory in its analysis (Queirós et al. 2017) }\end{array}$ & \\
\hline & $\begin{array}{l}\text {-Use of general academic and technical words which respondents were } \\
\text { familiar with. }\end{array}$ & \\
\hline \multirow[t]{2}{*}{$\begin{array}{l}\text { Geo- } \\
\text { spatial } \\
\text { analysis }\end{array}$} & \multirow[t]{2}{*}{$\begin{array}{l}\text {-Use of statistics and change detection among the classes used to provide } \\
\text { relevant information on spatial distribution of the drivers. }\end{array}$} & $\begin{array}{l}\text {-Limited assessment of indirect (non-spatial) drivers of } \\
\text { LUCC. }\end{array}$ \\
\hline & & $\begin{array}{l}\text {-Require detailed/advanced datasets to provide more } \\
\text { details on multiple factors influencing LUCC. Example: } \\
\text { Identify social and economic factors which contributed } \\
\text { most to the substantial increase in built up. }\end{array}$ \\
\hline
\end{tabular}

\section{Conclusion}

The paper primarily analyses local drivers that influence land cover change and land degradation in Southwestern Ghana using the mixed method approach. Conducting studies on microclimates related to LUCC is quite challenging. Local studies of this nature are fundamental to understanding the global earth systems and climate dynamics, along with the courses of action that need to be designed to ensure consistency with scientific explanations. Understanding direct and indirect drivers of LUCC along with its dynamics and prospect are essential in attaining United Nation's Sustainable Development Goals. Advocacy and concerns in the wake of our changing climate and observable changes in the earth system propel the need for further research that improves existing knowledge, innovation and inform the decisions of city planners, Municipal authority, researchers and interested organizations. Findings would enrich basic datasets that would assist land use planners and strategists in future modelling of land use systems. Based on results obtained using the MMA, it can be concluded that:

- A substantial increase in built-up and farmlands/shrubs areas have contributed to forests and LUCC in the study area.

- Contribution rate of change analysis revealed built-up areas contributed the most among other classes for the given indices.

- Change in prevailing microclimatic conditions, specifically surface temperature can be attributed to the undesirable and unprecedented changes in land use systems over the past 50 years.

- Biophysical, cultural and technological factors can be considered as key drivers despite the "medium-to-very low confidence" in results obtained, as they could potentially impact climate sensitive sectors that could significantly modify land use processes.

We presented an objective and a detailed framework to enhance reliability and validity of study findings using confidence level analysis. The underlying theories for the present study are anchored in sustainable livelihood frameworks, FTT, land use/land degradation and sustainable development. Therefore, the key drivers of LUCC that poses threats to livelihoods, ecosystem services can be examined holistically using an interdisciplinary approach to solve basic problems that stem regions without incurring unintended consequences. The present study hereby proposes further analyses of LUCC drivers with "medium to very low" confidence levels for further action. Again, local or regional studies of this nature influence global studies (international scientific community) by highlighting valid and reliable contributions or actions at the local or regional levels that drives significant change.

\section{Declarations}

\section{Data Availability}

Data that support study findings are available, and would be shared upon request.

\section{Acknowledgement}


The authors wish to express their sincere gratitude to Nanjing University of Information Science and Technology (NUIST) for making available relevant materials and creating an enabling environment, needed to complete this research. Special thanks go to the Research Institute for History of Science \& Technology, School of Law and Public Affairs for making available the datasets used for this study. This work was supported by the National Natural Science Foundation of China (No. 41971340 and No.41271410). The authors would like to thank the handling editor and anonymous reviewers for their careful reviews and helpful remarks.

\section{Conflict of Interest}

The authors declare that they have no competing interests.

\section{References}

1. Abbam, T., Johnson, F. A., Dash, J., \& Padmadas, S. S. (2018). Spatiotemporal variations in rainfall and temperature in Ghana over the twentieth century, 1900-2014. Earth and Space Science, 5,120-132. https://doi.org/10.1002/2017EA000327

2. Acheampong, M., Yu, Q., Enomah, D. L., Anchang, J., Eduful, M. (2018). Land use/cover change in Ghana's oil city: Assessing the impact of neoliberal economic policies and implications for sustainable development goal number one - A remote sensing and GIS approach. Land Use Policy, 73, 373-384. https://doi.org/10.1016/j.landusepol.2018.02.019

3. Addae, B. \& Oppelt, N. (2019). Land-use/land-cover change analysis and urban growth modelling in the Greater Accra Metropolitan Area (GAMA), Ghana. Urban Sci., 3, 26. DOI: https://doi.org/10.3390/urbansci3010026

4. Adjei, P.O.-W., Buor, D. \& Addrah, P. (2014). Geo-spatial analysis of land use and land cover changes in the Lake Bosomtwe Basin of Ghana. Ghana J. Geogr. 2014, 6, 1-23. DOI:10.4314/GJG.V6I1

5. Aduah, M. S. \& Baffoe, P. E. (2013). Remote Sensing for Mapping Land-Use/Cover Changes and Urban Sprawl in Sekondi-Takoradi, Western Region of Ghana. Int. J. of Eng. And Scie., 66-73.

6. Aduah, M. S., Mantey, S. and Tagoe, N. D. (2012). Mapping Land Surface Temperature and Land Cover to Detect Urban Heat Island Effect: A Case Study of Tarkwa, South West Ghana. Res. J. Environ. Earth Sci., 68-75.

7. Ahn, P.M. 1958. Regrowth and swamp vegetation in the western forest areas of Ghana. J. W. Afr. Sci Ass. 4: 163-73.

8. Alo, C.A., Pontius, R.G., Jr. (2008). Identifying systematic land-cover transitions using remote sensing and GIS: The fate of forests inside and outside protected areas of Southwestern Ghana. Environ. Plan. B Plan. Des, 35, 280-295. DOI: https://doi.org/10.1068/b32091

9. Amproche, A.A.; Antwi, M.; Kabo-Bah, A.T. Geospatial Assessment of Land Use and Land Cover Patterns in the Black Volta Basin. J. Remote Sens. GIS 2020, 9, 269. Doi:10.35248/2469-4134.20.9.269

10. Angelsen, A. \& Wunder, S. 2003. Exploring the forest-poverty link: Key concepts, issues and research implications. CIFOR Occasional Paper No. 40. Bogor, Indonesia: Center for International Forestry Research. DOI: 10.17528/cifor/001211

11. Aryeetey, E., \& Kanbur, R. (2008). The Economy of Ghana: Analytical Perspectives on Stability, Growth and Poverty. University of Ghana, Legon, 15-33. Doi: 10.7722/j.ctt81fmh

12. Arhin, K. 1985. The Expansion of Cocoa Production: The Working Conditions of Migrant Cocoa Farmers in Central and Western Regions. Legon: Institute of African Studies, University of Ghana.

13. Asante-Poku, A. \& Angelucci, F. (2013). Analysis of Incentives and Disincentives for Cocoa in Ghana; MAFAP, FAO: Rome, Italy. Doi: https://doi.org/10.21955/gatesopenres.1115955.1

14. Awotwi, A., Kumi, M., Jansson, P.E., Yeboah, F., Nti, I.K. (2015). Predicting hydrological responses to climate change in the White Volta catchment, West Africa. J. Earth Sci. Clim. Chang, 6, 249. Retrieved from http://hdl.handle.net/123456789/766

15. Awotwi, A., Anornu, G.K., Quaye-Ballard, J.A. \& Annor, T. (2018). Monitoring land use and land cover changes due to extensive gold mining, urban expansion, and agriculture in the Pra River Basin of Ghana, 1986-2025. Land Degrad. Dev, 29, 3331-3343. Doi: https://doi.org/10.1002/ldr.3093

16. Basommi, P.L., Guan, Q., Cheng, D. (2015). Exploring land use and land cover change in the mining areas of Wa East District, Ghana using satellite imagery. Open Geosci, 1, 618-626. DOI:10.1515/GEO-2015-0058

17. Bessah, E., Raji, A.O., Taiwo, O.J., Agodzo, S.K., Ololade, O.O., Strapasson, A. (2020). Hydrological responses to climate and land use changes: The paradox of regional and local climate effect in the Pra River Basin of Ghana. J. Hydrol. Reg. Stud, 27, 100654. Doi: https://doi.org/10.1016/j.ejrh.2019.100654

18. Bessah, E., Bala, A., Agodzo, S. K., Okhimamhe, A. A., Boakye, E. A., Ibrahim, S. U. (2019). "The impact of crop farmers' decisions on future land use, land cover changes in Kintampo North Municipality of Ghana", Int. J. of Clim. Ch. Strateg. and Mgt, 11, 72-87. DOI: https://doi.org/10.1108/IJCCSM-05-20170114

19. Boakye, E., Anornu, G.K., Quaye-Ballard, J.A., Donkor, E.A. (2018). Land use change and sediment yield studies in Ghana. J. Geogr. Reg. Plan, 11 , $122-133$. Doi: https://doi.org/10.5897/JGRP2018.0707

20. Brooke, J. 1989. Ghana, once 'Hopeless,' Gets At Least the Look of Success. The New York Times Archives. Retrieved from: https://www.nytimes.com/1989/01/03/world/ghana-once-hopeless-gets-at-least-the-look-of-success.html

21. Chakraborty, A. \& Joshi, P. K. (2014). Mapping disaster vulnerability in India using analytical hierarchy process. Geomatics, Natural Hazards and Risk, 20. doi:10.1080/19475705.2014.897656

22. Damnyag, L. Oduro, A. K, Obiri, D. B., Mohammed, Y., Bampoh, A. A. (2017). Assessment of Drivers of Deforestation and Forest Degradation in Bia-WestJuabeso landscape, Ghana. Ministry of Food \& Agriculture (MOFA) (Unpublished report).

Page $18 / 35$ 
23. Danumah, J.H., Odai, S.N., Saley, B.M. et al. Flood risk assessment and mapping in Abidjan district using multi-criteria analysis (AHP) model and geoinformation techniques, (cote d'ivoire). Geoenviron Disasters 3, 10 (2016). https://doi.org/10.1186/s40677-016-0044-y

24. Dei, G. 1988. Coping with the effects of the 1982-83 drought in Ghana: The view from the village. Africa Development / Afrique Et Développement, 107122. Retrieved November 28, 2020 from http://www.jstor.org/stable/24486648

25. Dickson, K.B. \& Benneh. G. (1988). A New Geography of Ghana. London Longman Group.

26. Ellis, E. \& Pontius, R., (2010). Land-use and land-cover change. In: Encyclopaedia of Earth. Eds. Cutler J. Cleveland (Washington, D.C.: Environmental Information Coalition, National Council for Science and the Environment. Retrieved December 16, 2020 from http://www.eoearth.org/article/Landuse_and_land-cover_change.

27. FAO. 2013. Climate change guidelines for forest managers. FAO Forestry Paper No. 172, Rome, Food and Agriculture Organization of the United Nations. Retrieved from www.fao.org/3/i3383e/i3383e00.htm

28. Foley, J.A., DeFries, R., Asner, G.P., Barford, C., Bonan, G., Carpenter, S., Chapin, F.S., Coe, M., Daily, G., Gibbs, H., Helkowski, J., Holloway, T., Howard, E., Kucharik, C., Monfreda, C., Patz, J., Prentice, I., Ramankutty, N., Snyder, P. (2005). Global consequences of land use. Science 309, $570-574$. DOI: $10.1126 /$ science. 1111772

29. Gazzola, P., \& Querci, E. (2017). The connection between the quality of life and sustainable ecological development. European Scientific Journal, 361-375. https://doi.org/10.19044/esj.2017.v13n12p\%p

30. Geiger, M.T., Kwakye, K.G., Vicente, C.L., Wiafe, B.M., Boakye Adjei, N.Y. (2019). Fourth Ghana Economic Update: Enhancing Financial Inclusion - Africa Region (English). Ghana Economic Update,no. 4 Washington, D.C. : World Bank Group. Retrieved from:

http://documents.worldbank.org/curated/en/395721560318628665/Fourth-Ghana-Economic-Update-Enhancing-Financial-Inclusion-Africa-Region.

31. Ghulam, A. (2010). Calculating surface temperature using Landsat thermal imagery. Department of Earth \& Atmospheric Sciences, and Center for Environmental Sciences, St. Louis University, MO 63103. Retrieved from https: //serc.carleton.edu/NAGTWorkshops/gis/activities2/48433.html

32. Gockowski, J. \& Sonwa. D. (2011). "Cocoa intensification scenarios and their predicted impact on $\mathrm{CO}_{2}$ emissions, biodiversity conservation, and rural livelihoods in the Guinea rain forest of West Africa." Environmental Management 48: 307-321. DOI:10.1007/s00267-010-9602-3

33. Gyasi, E.A., Agyepong, G. T., Ardayfio-Schandorf, E., Enu-Kwesi, L., Nabila, J. S. \& Owusu Bennoah, E. (1994). Environmental Endangerment in the ForestSavanna Zone of Southern Ghana: A Research Study Report. Tokyo: UNU. Retrieved from https://archive.unu.edu/env/plec/country/ghana/Ghana.doc.

34. Hall, J.B. \& Swaine, M.D. (1976): Classification and ecology of closed-canopy forest in Ghana. Journal of Ecology, 64, 913-951. Doi:10.2307/2258816

35. Haradhan, M. (2018). Qualitative Research Methodology in Social Sciences and related subjects. Journal of Economic Development, Environment and People, 23-48. DOI:10.26458/jedep.v7i1.571

36. Huq, M and Tribe, M. (2018). The Economy of Ghana: 50 Years of Economic Development. Palgrave Macmillan, London. DOI: https://doi.org/10.1057/978-1-137-60243-5

37. Hyden, G. 1998. Governance for sustainable livelihoods: operational issues. UNDP, New York.

38. Jacobs, S., Burkhard, B., Van Daele, T., Staes, J., \& Schneiders, A. (2015). 'The Matrix Reloaded': A review of expert knowledge use for mapping ecosystem services. Ecological Modelling, 295, 21-30. DOI: http://dx.doi.org/10.1016/j.ecolmodel.2014.08.024

39. Kleemann, J., Inkoom, N. J., Thiel, M., Shankar, S., Lautenbach, S., Fürst, C. (2017). Peri-urban land use pattern and its relation to land use planning in Ghana, West Africa. Landscape and Urban Planning 165 (2017) 280-294. Doi: http://dx.doi.org/10.1016/j.landurbplan.2017.02.004

40. Koranteng, A., Donkor, E., Zawila-Niedzwiecki, T. \& Kombat, D. (2017). Synergies of Satellite Images for Forest Loss and other Land Use Study in Ghana. International Conference on Applied Sciences and Technology (ICAST), Kumasi Technical University, 4, 211-228

41. Koranteng, A.; Adu-Poku, I.; Zawila-Niedzwiecki, T. (2017). Drivers of land use change and carbon mapping in the savannah area of Ghana. Folia For. Pol., 59, 287-311. Doi: https://doi.org/ 10.3390/su13094951

42. Kusi, N. 1991. Ghana: Can the Adjustment Reforms be Sustained? Africa Development / Afrique Et Développement, 16(3/4), 181-206. Retrieved November 28, 2020, from http://www.jstor.org/stable/43657861

43. Kusimi, J.M. (2008). Assessing land use and land cover change in the Wassa West District of Ghana using remote sensing. GeoJournal, 71, $249-259$. DOI: https://doi.org/10.1007/s10708-008-9172-6

44. Lambin, E. F., \& Meyfroidt, P. (2011). Global land use change, economic globalization, and the looming land scarcity. Proceedings of the National Academy of Sciences, 108, 3465-3472. DOI: 10.1073/pnas.1100480108

45. Leemhuis, C.; Jung, G.; Kasei, R.; Liebe, J. (2009). The Volta Basin water allocation system: Assessing the impact of small-scale reservoir development on the water resources of the Volta Basin, West Africa. Adv. Geosci, 21, 57-62. Doi: https://doi.org/10.5194/adgeo-21-57-2009, 2009.

46. Logah, F.Y., Obuobie, E., Ofori, D. and Kankam-Yeboah, K. (2013). "Analysis of Rainfall Variability in Ghana”. International Journal of Latest Research in Engineering and Computing (IJLREC), 1(1), 1-8.

47. MA. (2005). Ecosystems and human well-being: Synthesis. Millennium Ecosystem Assessment (MA). Washington, DC: Island Press.

48. Mastrandrea, M.D., Mach, K.J., Plattner, G.-K., Edenhofer, O., Stocker, T.F., et al., 2011. The IPCC AR5 guidance note on consistent treatment of uncertainties: a common approach across the working groups. Clim. Change. DOI: http://dx.doi.org/ 10.1007/s10584-011-0178-6.

49. Mather, A., Needle, C., Coull, J., 1998. From resource crisis to sustainability: the forest transition in Denmark. International Journal of Sustainable Development and World Ecology, 5, 183-192. DOI: https://doi.org/10.1080/13504509809469982

50. McGregor, D.F.M., Adam-Bradford, A., Thompson, D.A., Simon, D. (2011). Resource management and agriculture in the peri-urban interface of Kumasi, Ghana: Problems and prospects. Singap. J. Trop. Geogr., 32, 382-398. DOI:10.1111/J.1467-9493.2011.00438.X

Page 19/35 
51. Mensah, C. A., Eshun, J. K., Asamoah, Y. \& Ofori, E. (2019) Changing land use/cover of Ghana's oil city (Sekondi-Takoradi Metropolis): implications for sustainable urban development, International Journal of Urban Sustainable Development, 11:2, 223-233, D0I: 10.1080/19463138.2019.1615492

52. Meyfroidt, P., \& Lambin, E. F. (2011). Global forest transition: prospects for an end to deforestation. Annual review of environment and resources, 36, 343371. DOI: https://doi.org/10.1146/annurev-environ-090710-143732

53. Moller-Jensen, L., Knudsen, M.H. (2006). Patterns of population change in Ghana (1984-2000): urbanization and frontier development. GeoJourna/73, 307-320 (2008). Doi: https://doi.org/10.1007/s10708-008-9209-x

54. Nasi, R., \& Frost, P. G. (2009). Sustainable forest management in the tropics: is everything in order but the patient still dying? Ecology and Society, 14. Retrieved November 4, 2020, from https://hdl.handle.net/10568/20266

55. Nejad, A. R. V., Esmaeili S. \& Aghamohammadi, H. (2015). Earthquake Risk Modeling using GIS for urban buildings, Case study: Tehran Municipality, District 3. Advances in Natural \& Applied Sciences, 9, 33-43. Retrieved from http://www.unocha.org/cotedivoire/maps-graphics/thematic-maps

56. Nikoi, E. 2015. Ghana's Economic Recovery Programme and the Globalisation of Ashanti Goldfields Company Ltd. Journal of Int. Dev. Vol. 28 (4), pp. 588605. DOI: https://doi.org/10.1002/jid.3199

57. Noponen, R. A. M., Mensah, D. B. C., Schroth G., Hayward, J. (2014). A landscape approach to climate-smart agriculture in Ghana. ETFRN News 56. Retrieved from https://www.rainforest-alliance.org/sites/default/files/2016-08/A-landscape-approach-to-climate-smart-agriculture-in-Ghana.pdf.

58. Obeng-Odoom, F. (2013). Resource curse or blessing in Africa's oil cities? Empirical evidence from Sekondi-Takoradi, West Africa. City Cult. Soc., 4, 229240. Doi: 10.1016/j.ccs.2013.07.001

59. Oti, J.O., Kabo-Bah, A.T., Ofosu, E. (2020). Hydrologic response to climate change in the Densu River Basin in Ghana. Heliyon, 6: e04722. DOI: 10.1016/j.heliyon.2020.e04722

60. Owusu-Nimo, F., Mantey, J., Nyarko, K.B., Appiah-Effah, E., Aubynn. A. (2018). Spatial distribution patterns of illegal artisanal small scale gold mining (Galamsey) operations in Ghana: A focus on the Western Region, Heliyon, 4. Doi: https://doi.org/10.1016/j.heliyon.2018.e00534.

61. Queirós, A., Faria, D., and Almeida, F. (2017). Strengths and Limitations of Qualitative and Quantitative research methods. European J.of Edu.Studies Vol. 3 (9): 369-387. doi: 10.5281/zenodo.887089

62. Rudel, T. K., Meyfroidt, P., Chazdon, R., Bongers, F., Sloan, S., Grau, H. R., Schneider, L. (2020). Whither the forest transition? Climate change, policy responses, and redistributed forests in the twenty-first century. Ambio, 49, 74-84. https://doi.org/10.1007/s13280-018-01143-0

63. Rindfuss, R.R. \& Stern, P.C., (1998). Linking remote sensing and social science: the need and the challenges. The National Academy Press, Washington, D.C.

64. Rudel, Thomas \& Schneider, Laura \& Uriarte, María. (2010). Forest transitions: An introduction. Land Use Policy. 27. 95-97. DOI: 10.1016/j.landusepol.2009.09.021.

65. Saad, A., Shariff, N. \& Gairola, S. (2013). Nature and causes of land degradation and desertification in Libya: Need for sustainable land management. Afr. J. Biotechnol, 10, 13680-13687. Doi: 10.5897/AJB11.1235

66. Saaty, T. L. 1980. The Analytic Hierarchy Process: Planning, Priority setting, Resource allocation, McGraw-Hill International Book Co., New York. DOI:10.1016/0377-2217(82)90022-4

67. Sarfo, I., Shuoben, B., Beibei, L. et al. (2021). Spatiotemporal development of land use systems, influences and climate variability in Southwestern Ghana (1970-2020). Environ Dev Sustain (2021), 1-34. https://doi.org/10.1007/s10668-021-01848-5

68. Sim, H. C., Appanah, S., \& Youn, Y. C. (2004). Forests for poverty reduction: opportunities with clean development mechanism, environmental services and biodiversity. Proceedings of the workshop, 27-29 August 2003, Seoul National University, Korea. Retrieved from http://www.fao.org/3/ae537e/ae537e00.htm

69. Smith, J. \& Scherr, S. J. (2002). Forest carbon and local livelihoods: assessment of opportunities and policy recommendations. Occasional Paper No. 37. Bogor. CIFOR. 45 pp. Retrieved from http://www.cifor.cgiar.org/publications/pdf_files/OccPapers/OP-037.pdf

70. Southworth, J., Nagendra, H., \& Cassidy, L. (2012). Forest transition pathways in Asia-studies from Nepal, India, Thailand, and Cambodia. Journal of Land Use Science, 7, 51-65. DOI: 10.1080/1747423X.2010.520342

71. Tahiru, A.A., Doke, D.A. \& Baatuuwie, B.N. (2020). Effect of land use and land cover changes on water quality in the Nawuni Catchment of the White Volta Basin, Northern Region, Ghana. Appl. Water Sci., 10, 1-14. Doi: https://doi.org/10.1007/s13201-020-01272-6

72. Tan C.M. \& Rockmore M. (2018). Famine in Ghana and Its Impact. In: Preedy V., Patel V. (eds) Handbook of Famine, Starvation, and Nutrient Deprivation. Springer, Cham. DOI: https://doi.org/10.1007/978-3-319-40007-5_95-1

73. Tolessa, T., Dechassa, C., Simane, B., Alamerew, B. \& Kidane, M. (2019). Land use/Land cover dynamics in response to various driving forces in Didessa sub-basin, Ethiopia. GeoJournal 85, 747-760. https://doi.org/10.1007/s10708-019-09990-4.

74. Turner, B.L., Lambin, E., Reenberg, A., 2007. Land change science special feature: the emergence of land change science for global environmental change and sustainability. Proceedings of the National Academy of Sciences of the United States of America 104, 20666-20671. DOI: https://doi.org/10.1073/pnas.0704119104

75. Waggoner, P. E., \& Ausubel, J. H. (2001). How much will feeding more and wealthier people encroach on forests? Population and development review, 27, 239-257.

76. Xu, H. (2007): Extraction of urban built-up land features from Landsat imagery using a thematic-oriented index combination technique. Photogrammetric Eng. \& Remote Sens. 73: 1381-1391. DOI:10.14358/PERS.73.12.1381

\section{Annex li}

Page 20/35 
Annex II: Ground-truthing sample points using MDC for each class in the study domain

Page $21 / 35$ 


\begin{tabular}{|c|c|c|c|}
\hline Town Name & Land Cover Type & Latitude & Longitude \\
\hline Abochia & Forest & 5.7724304 & -2.7417033 \\
\hline Abochia & Waterbodies & 5.7747888 & -2.7373905 \\
\hline Aboi Nkwanta & Farmlands/Shrubs & 5.7731764 & -2.4790277 \\
\hline Aboi Nkwanta & Farmlands/Shrubs & 5.7757688 & -2.4720021 \\
\hline Aboi Nkwanta & Bare land & 5.7909471 & -2.4638667 \\
\hline Aboi Nkwanta & Farmlands/Shrubs & 5.7867807 & -2.4662858 \\
\hline Aboi Nkwanta & Farmlands/Shrubs & 5.795318 & -2.459068 \\
\hline Aboi Nkwanta & Built-up & 5.7976689 & -2.4550062 \\
\hline Aboi Nkwanta & Bare land & 5.8016515 & -2.4493658 \\
\hline Abokyia & Built-up & 5.7721831 & -2.7444794 \\
\hline Abora & Built-up & 5.6247933 & -2.223478 \\
\hline Abora & Farmlands/Shrubs & 5.6247933 & -2.223478 \\
\hline Abora & Built-up & 5.6247933 & -2.223478 \\
\hline Abora & Farmlands/Shrubs & 5.6247933 & -2.223478 \\
\hline Achichire & Built-up & 5.7116363 & -2.3274181 \\
\hline Achichire & Farmlands/Shrubs & 5.7038642 & -2.3239394 \\
\hline Achichire & Farmlands/Shrubs & 5.6752853 & -2.3058358 \\
\hline Achichire & Farmlands/Shrubs & 5.6645194 & -2.2980422 \\
\hline Achimfo & Bare land & 5.778455 & -2.7310312 \\
\hline Achimfo & Forest & 5.7794714 & -2.7303202 \\
\hline Achimfo & Waterbodies & 5.7824016 & -2.7297608 \\
\hline Achimfo & Built-up & 5.7828116 & -2.726489 \\
\hline Achimfo & Built-up & 5.7831558 & -2.7276108 \\
\hline Achimfo & Forest & 5.7833488 & -2.7290849 \\
\hline Achimfo & Bare land & 5.778695 & -2.7309494 \\
\hline Achimfo & Waterbodies & 5.77784 & -2.7319652 \\
\hline Achimfo & Forest & 5.7761414 & -2.7332229 \\
\hline Achimfo & Forest & 5.7749629 & -2.7340713 \\
\hline Achimfo & Forest & 5.7750415 & -2.7378088 \\
\hline Adjakaa & Farmlands/Shrubs & 5.7731549 & -2.7626148 \\
\hline Adjakaa & Built-up & 5.7728571 & -2.7612506 \\
\hline Adjakaa & Built-up & 5.7726524 & -2.7601049 \\
\hline Adjakaa & Forest & 5.7722928 & -2.7570706 \\
\hline Adjakaa & Waterbodies & 5.7722473 & -2.7566832 \\
\hline Adjakaa & Built-up & 5.7723433 & -2.7526647 \\
\hline Adjakaa & Bare land & 5.7726107 & -2.7517878 \\
\hline Adjakaa & Built-up & 5.7718865 & -2.7482012 \\
\hline Adjakaa & Farmlands/Shrubs & 5.7729035 & -2.7412537 \\
\hline Adjakaa & Built-up & 5.7722726 & -2.7435331 \\
\hline Adjakaa & Farmlands/Shrubs & 5.7727648 & -2.75002 \\
\hline Adjakaa & Bare land & 5.7728384 & -2.7505657 \\
\hline Adjakaa & Farmlands/Shrubs & 5.7723826 & -2.7529477 \\
\hline Adjakaa & Farmlands/Shrubs & 5.7723826 & -2.7529477 \\
\hline Adjakaa & Farmlands/Shrubs & 5.7723271 & -2.7567217 \\
\hline Adjakaa & Built-up & 5.772843 & -2.7610071 \\
\hline Adjakaa & Farmlands/Shrubs & 5.774871 & -2.763657 \\
\hline Adjakaa & Forest & 5.7762445 & -2.7642983 \\
\hline Adjakaa & Farmlands/Shrubs & 5.7789471 & -2.7675303 \\
\hline Adjakaa & Farmlands/Shrubs & 5.7801503 & -2.7700112 \\
\hline Adjakaa & Farmlands/Shrubs & 5.7806319 & -2.7725103 \\
\hline Adjakaa & Farmlands/Shrubs & 5.7809644 & -2.7743215 \\
\hline Adjakaa & Farmlands/Shrubs & 5.7812677 & -2.7759535 \\
\hline Adjakaa & Bare land & 5.7816694 & -2.7781994 \\
\hline Adjakaa & Forest & 5.7815595 & -2.7810551 \\
\hline Agona & Bare land & 4.9795824 & -2.002476 \\
\hline Agona & Forest & 4.9604026 & -1.9798008 \\
\hline Agona & Built-up & 4.948206 & -1.9789434 \\
\hline Agona & Bare land & 4.9307693 & -1.9773826 \\
\hline Agona & Forest & 4.9294022 & -1.9772507 \\
\hline Agona nkwanta & Forest & 4.9242317 & -1.9775407 \\
\hline Agona nkwanta & Built-up & 4.9042831 & -1.9703604 \\
\hline Agona nkwanta & Built-up & 4.890716 & -1.959516 \\
\hline Agona nkwanta & Farmlands/Shrubs & 4.8960616 & -1.9337102 \\
\hline Agona nkwanta & Built-up & 4.9014313 & -1.9118607 \\
\hline Agona nkwanta & Waterbodies & 4.9017983 & -1.9058699 \\
\hline Agona nkwanta & Built-up & 4.8919269 & -1.8650352 \\
\hline Agona nkwanta & Farmlands/Shrubs & 4.892803 & -1.8481021 \\
\hline Agona nkwanta & Built-up & 4.8926576 & -1.8228637 \\
\hline Agona nkwanta & Built-up & 4.9077653 & -1.7985792 \\
\hline Amenfi central & Forest & 5.6314968 & -2.2367701 \\
\hline Amenfi central & Bare land & 5.6320024 & -2.2288169 \\
\hline
\end{tabular}

Page 22/35 


\begin{tabular}{|c|c|c|c|}
\hline Amenfi central & Built-up & 5.6312013 & -2.22762 \\
\hline Amoakrom & Farmlands/Shrubs & 5.7628641 & -2.4101565 \\
\hline Amoakrom & Farmlands/Shrubs & 5.7613876 & -2.4052803 \\
\hline Amoakrom & Forest & 5.7594411 & -2.3998685 \\
\hline Amoakrom & Built-up & 5.7569353 & -2.396663 \\
\hline Amoamang & Farmlands/Shrubs & 5.7671017 & -2.4998874 \\
\hline Amoamang & Built-up & 5.7695093 & -2.4898881 \\
\hline Amoamang & Built-up & 5.7689285 & -2.4917864 \\
\hline Amoamang & Built-up & 5.7745352 & -2.4753451 \\
\hline Asan & Forest & 5.7796136 & -2.7125955 \\
\hline Asan & Farmlands/Shrubs & 5.7837252 & -2.7051619 \\
\hline Asan & Farmlands/Shrubs & 5.7876262 & -2.6974838 \\
\hline Asan & Built-up & 5.7907073 & -2.6923852 \\
\hline Asan & Farmlands/Shrubs & 5.7952261 & -2.6819038 \\
\hline Asankagua & Forest & 5.7815053 & -2.7915585 \\
\hline Asankagua & Farmlands/Shrubs & 5.7820792 & -2.7894839 \\
\hline Asankagua & Farmlands/Shrubs & 5.7815712 & -2.7839699 \\
\hline Asankagua & Farmlands/Shrubs & 5.779979 & -2.7696997 \\
\hline Asankragua & Built-up & 5.8037103 & -2.4474133 \\
\hline Asankragua & Built-up & 5.8063783 & -2.4459083 \\
\hline Asankragua & Built-up & 5.8093825 & -2.438074 \\
\hline Asankragua & Built-up & 5.8078821 & -2.4352706 \\
\hline Asankragua & Built-up & 5.8054283 & -2.432525 \\
\hline Asankragua & Built-up & 5.8069744 & -2.4340065 \\
\hline Asankragua & Bare land & 5.7935903 & -2.427006 \\
\hline Asankragua & Farmlands/Shrubs & 5.7910534 & -2.4235698 \\
\hline Asankragua & Bare land & 5.7768976 & -2.4191112 \\
\hline Asankragua & Farmlands/Shrubs & 5.7656394 & -2.4141844 \\
\hline Asantekrom & Built-up & 5.7765948 & -2.6216944 \\
\hline Asantekrom & Farmlands/Shrubs & 5.7731084 & -2.6085383 \\
\hline Asantekrom & Farmlands/Shrubs & 5.7740441 & -2.6109621 \\
\hline Asantekrom & Farmlands/Shrubs & 5.7696406 & -2.601916 \\
\hline Asantekrom & Built-up & 5.7676215 & -2.6004611 \\
\hline Bawdie & Farmlands/Shrubs & 5.6247933 & -2.223478 \\
\hline Bawdie & Forest & 5.6247933 & -2.223478 \\
\hline Bawdie & Forest & 5.6247933 & -2.223478 \\
\hline Bawdie & Built-up & 5.6247933 & -2.223478 \\
\hline Bawdie & Built-up & 5.6247933 & -2.223478 \\
\hline Bawdie & Farmlands/Shrubs & 5.6247933 & -2.223478 \\
\hline Bawdie & Farmlands/Shrubs & 5.6247933 & -2.223478 \\
\hline Bawdie & Built-up & 5.6247933 & -2.223478 \\
\hline Bawdie & Built-up & 5.6247933 & -2.223478 \\
\hline Bawdie & Bare land & 5.6247933 & -2.223478 \\
\hline Bawdie & Bare land & 5.6247933 & -2.223478 \\
\hline Bawdie & Farmlands/Shrubs & 5.6247933 & -2.223478 \\
\hline Bawdie & Built-up & 5.6247933 & -2.223478 \\
\hline Bawdie & Built-up & 5.6247933 & -2.223478 \\
\hline Bawdie & Built-up & 5.6247933 & -2.223478 \\
\hline Bawdie & Farmlands/Shrubs & 5.6247933 & -2.223478 \\
\hline Bawdie & Bare land & 5.6247933 & -2.223478 \\
\hline Bawdie & Built-up & 5.6247933 & -2.223478 \\
\hline Bawdie & Farmlands/Shrubs & 5.6247933 & -2.223478 \\
\hline Bawdie & Waterbodies & 5.6247933 & -2.223478 \\
\hline Bawdie & Farmlands/Shrubs & 5.6247933 & -2.223478 \\
\hline Bawdie & Built-up & 5.6247933 & -2.223478 \\
\hline Bawdie & Built-up & 5.6247933 & -2.223478 \\
\hline Bawdie & Built-up & 5.6247933 & -2.223478 \\
\hline Bawdie & Built-up & 5.3210119 & -1.9858939 \\
\hline Bawdie & Bare land & 5.3170418 & -1.9891407 \\
\hline Bawdie & Built-up & 5.3137893 & -1.9905549 \\
\hline Bawdie & Built-up & 5.308967 & -1.993578 \\
\hline Bawdie & Built-up & 5.306455 & -1.9949467 \\
\hline Bawdie & Built-up & 5.306088 & -1.9941129 \\
\hline Beposo & Built-up & 5.117733421 & -1.620969462 \\
\hline Beposo & Waterbodies & 5.123176862 & -1.617846847 \\
\hline Beposo & Built-up & 5.123848452 & -1.613322879 \\
\hline Beposo & Farmlands/Shrubs & 5.123794395 & -1.609115739 \\
\hline Beposo & Farmlands/Shrubs & 5.123946226 & -1.606856831 \\
\hline Beposo & Farmlands/Shrubs & 5.121201241 & -1.603611216 \\
\hline Beposo & Farmlands/Shrubs & 5.119131043 & -1.603644784 \\
\hline Beposo & Farmlands/Shrubs & 5.110649444 & -1.600790656 \\
\hline Bogoso & Forest & 5.6247933 & -2.223478 \\
\hline
\end{tabular}

Page 23/35 


\begin{tabular}{|c|c|c|c|}
\hline Bogoso & Farmlands/Shrubs & 5.6247933 & -2.223478 \\
\hline Bogoso & Farmlands/Shrubs & 5.6247933 & -2.223478 \\
\hline Bogoso & Built-up & 5.6247933 & -2.223478 \\
\hline Bogoso & Forest & 5.6247933 & -2.223478 \\
\hline Bogoso & Bare land & 5.6315684 & -2.2280839 \\
\hline Bogoso & Farmlands/Shrubs & 5.6247933 & -2.223478 \\
\hline Bogoso & Built-up & 5.6247933 & -2.223478 \\
\hline Bogoso & Built-up & 5.6247933 & -2.223478 \\
\hline Bogoso & Farmlands/Shrubs & 5.6247933 & -2.223478 \\
\hline Bogoso & Waterbodies & 5.6247933 & -2.223478 \\
\hline Bonsa & Waterbodies & 5.1805041 & -2.0429004 \\
\hline Bonsa & Built-up & 5.1786821 & -2.0449472 \\
\hline Bonsa & Farmlands/Shrubs & 5.1775916 & -2.04999 \\
\hline Bonsa & Forest & 5.1742762 & -2.0526224 \\
\hline Bonsa & Farmlands/Shrubs & 5.1715467 & -2.0547386 \\
\hline Bonsa & Forest & 5.1702977 & -2.0607458 \\
\hline Bonsa & Farmlands/Shrubs & 5.1659001 & -2.0694848 \\
\hline Bonsa & Built-up & 5.158224 & -2.0751867 \\
\hline Bonsa & Built-up & 5.1555357 & -2.0757217 \\
\hline Bonsa & Farmlands/Shrubs & 5.1522493 & -2.0792259 \\
\hline Bonsa & Forest & 5.1513079 & -2.0814549 \\
\hline Bonsa & Bare land & 5.1479521 & -2.0846719 \\
\hline Bonsa & Farmlands/Shrubs & 5.1450881 & -2.0865302 \\
\hline Bonsa & Bare land & 5.1373192 & -2.091567 \\
\hline Bonsa & Farmlands/Shrubs & 5.1347235 & -2.0950671 \\
\hline Bonsa & Bare land & 5.1339535 & -2.0951517 \\
\hline Bonsa & Built-up & 5.1311083 & -2.095586 \\
\hline Bonsa & Forest & 5.040257 & -2.0871845 \\
\hline Bonsa & Forest & 5.00367 & -2.0680619 \\
\hline Bonsa & Forest & 5.0021238 & -2.0622763 \\
\hline Bonsa & Forest & 5.0030167 & -2.0480745 \\
\hline Bonsa & Built-up & 4.8990194 & -1.9643569 \\
\hline Bonsa & Farmlands/Shrubs & 4.8972505 & -1.9621961 \\
\hline Bonsa & Built-up & 4.8907609 & -1.9554344 \\
\hline Bonsa & Farmlands/Shrubs & 4.891974 & -1.9486254 \\
\hline Bonsa & Built-up & 4.8992058 & -1.9012358 \\
\hline Bonsa & Built-up & 4.8947931 & -1.8970939 \\
\hline Bonsa & Built-up & 4.8921061 & -1.8188959 \\
\hline Bonsa & Bare land & 4.8991231 & -1.8045651 \\
\hline Bonsa & Forest & 5.126423 & -2.0990707 \\
\hline Bonsa & Bare land & 5.1012162 & -2.1123051 \\
\hline Bonsa & Forest & 5.0983034 & -2.1108655 \\
\hline Bonsa & Built-up & 5.083397 & -2.1098058 \\
\hline Bonsa & Forest & 5.0815369 & -2.1097138 \\
\hline Bonsa & Forest & 5.0378687 & -2.0870709 \\
\hline Bonsa & Forest & 5.0059842 & -2.0765298 \\
\hline Bonsa & Forest & 4.9754866 & -1.9974092 \\
\hline Brodzekrom & Built-up & 5.749773 & -2.3953311 \\
\hline Brodzekrom & Bare land & 5.7471044 & -2.3943361 \\
\hline Brodzekrom & Forest & 5.7454052 & -2.3911821 \\
\hline Brodzekrom & Farmlands/Shrubs & 5.7449032 & -2.3894228 \\
\hline Brodzekrom & Farmlands/Shrubs & 5.7439919 & -2.3870871 \\
\hline Daboase & Farmlands/Shrubs & 5.111464612 & -1.632404093 \\
\hline Daboase & Bare land & 5.112116687 & -1.630525318 \\
\hline Daboase & Bare land & 5.11215884 & -1.629173686 \\
\hline Daboase & Farmlands/Shrubs & 5.112839892 & -1.623764691 \\
\hline Daboase & Farmlands/Shrubs & 5.114032808 & -1.622196952 \\
\hline Daboase & Built-up & 5.115987034 & -1.621303913 \\
\hline Densam & Farmlands/Shrubs & 5.6976839 & -2.3175873 \\
\hline Densam & Built-up & 5.6830614 & -2.3102984 \\
\hline Densam & Forest & 5.6708519 & -2.3029933 \\
\hline Densam & Farmlands/Shrubs & 5.6685109 & -2.3012083 \\
\hline Densam & Forest & 5.6556802 & -2.2923515 \\
\hline Densam & Forest & 5.6518927 & -2.2890249 \\
\hline Densam & Built-up & 5.6403035 & -2.2641269 \\
\hline Densam & Built-up & 5.6344357 & -2.2533786 \\
\hline Densam & Built-up & 5.633259 & -2.2475251 \\
\hline Densam & Farmlands/Shrubs & 5.6247933 & -2.223478 \\
\hline Densam & Farmlands/Shrubs & 5.6247933 & -2.223478 \\
\hline Densam & Farmlands/Shrubs & 5.6247933 & -2.223478 \\
\hline Densam & Built-up & 5.6247933 & -2.223478 \\
\hline Elubo & Farmlands/Shrubs & 5.7761464 & -2.7925709 \\
\hline
\end{tabular}

Page 24/35 


\begin{tabular}{|c|c|c|c|}
\hline Elubo & Forest & 5.7742342 & -2.7355266 \\
\hline Elubo & Built-up & 5.7830923 & -2.7278872 \\
\hline Elubo road & Forest & 5.7779138 & -2.794478 \\
\hline Enchi & Built-up & 5.8218236 & -2.823244 \\
\hline Enchi & Bare land & 5.8187036 & -2.8250094 \\
\hline Enchi & Farmlands/Shrubs & 5.81723 & -2.8244014 \\
\hline Enchi & Built-up & 5.8138331 & -2.8249005 \\
\hline Enchi & Forest & 5.7971596 & -2.8128529 \\
\hline Enchi & Farmlands/Shrubs & 5.7882961 & -2.8082597 \\
\hline Enchi & Farmlands/Shrubs & 5.782555 & -2.800649 \\
\hline Enchi & Built-up & 5.7812364 & -2.795622 \\
\hline Enchi & Built-up & 5.7818456 & -2.7985412 \\
\hline Enchi & Farmlands/Shrubs & 5.7839101 & -2.8020767 \\
\hline Enchi & Bare land & 5.7850223 & -2.8049192 \\
\hline Enchi & Forest & 5.7873294 & -2.8074895 \\
\hline Enchi & Farmlands/Shrubs & 5.7911184 & -2.811428 \\
\hline Enchi & Farmlands/Shrubs & 5.7931413 & -2.8123355 \\
\hline Enchi & Bare land & 5.7952845 & -2.8126209 \\
\hline Enchi & Farmlands/Shrubs & 5.797293 & -2.8128019 \\
\hline Enchi & Built-up & 5.7993413 & -2.8146221 \\
\hline Enchi & Farmlands/Shrubs & 5.8013314 & -2.8175672 \\
\hline Enchi & Bare land & 5.801264 & -2.8197241 \\
\hline Enchi & Bare land & 5.8019052 & -2.8222639 \\
\hline Enchi & Built-up & 5.8041878 & -2.8245258 \\
\hline Enchi & Bare land & 5.8067581 & -2.8264036 \\
\hline Enchi & Built-up & 5.8117791 & -2.8239717 \\
\hline Enchi & Built-up & 5.8165268 & -2.8254751 \\
\hline Enchi & Built-up & 5.8212664 & -2.8241698 \\
\hline Enchi & Built-up & 5.8210413 & -2.8237789 \\
\hline Enchi & Forest & 5.7903133 & -2.810635 \\
\hline Enchi & Farmlands/Shrubs & 5.7824391 & -2.785523 \\
\hline Enchi & Bare land & 5.7826888 & -2.7863125 \\
\hline Enchi & Bare land & 5.7825047 & -2.7881924 \\
\hline Enchi & Bare land & 5.7822519 & -2.7891373 \\
\hline Enchi & Farmlands/Shrubs & 5.8151338 & -2.825148 \\
\hline Enchi & Built-up & 5.8152138 & -2.8249673 \\
\hline Enchi & Waterbodies & 5.8193689 & -2.8252261 \\
\hline Fiaseman & Built-up & 5.2934604 & -1.9974524 \\
\hline Fiaseman & Built-up & 5.2892638 & -1.9983913 \\
\hline Fiaseman & Built-up & 5.2859559 & -2.0004871 \\
\hline Fiaseman & Built-up & 5.2791985 & -2.0030336 \\
\hline Fiaseman & Built-up & 5.2720263 & -2.0067614 \\
\hline Fiaseman & Built-up & 5.2668272 & -2.0065923 \\
\hline Fiaseman & Built-up & 5.2640872 & -2.0059469 \\
\hline Fiaseman & Built-up & 5.2609297 & -2.0041441 \\
\hline Fiaseman & Built-up & 5.258688 & -2.0035201 \\
\hline Fiaseman & Bare land & 5.2533505 & -2.0045141 \\
\hline Fiaseman & Built-up & 5.2455448 & -2.0065081 \\
\hline Fiaseman & Bare land & 5.2444319 & -2.0069979 \\
\hline Fiaseman & Farmlands/Shrubs & 5.2402845 & -2.0094957 \\
\hline Fiaseman & Built-up & 5.237618 & -2.0111993 \\
\hline Fiaseman & Built-up & 5.2337935 & -2.0127482 \\
\hline Fiaseman & Farmlands/Shrubs & 5.2260888 & -2.0167859 \\
\hline Fiaseman & Forest & 5.2218063 & -2.0201238 \\
\hline Gran & Forest & 5.7178788 & -2.3514529 \\
\hline Gran & Farmlands/Shrubs & 5.715202 & -2.3470061 \\
\hline Gran & Farmlands/Shrubs & 5.7175327 & -2.3359171 \\
\hline Gran & Farmlands/Shrubs & 5.6922546 & -2.3115557 \\
\hline Hiawa & Built-up & 5.6247933 & -2.223478 \\
\hline Hiawa & Built-up & 5.6247933 & -2.223478 \\
\hline Hiawa & Built-up & 5.6247933 & -2.223478 \\
\hline Hiawa & Farmlands/Shrubs & 5.6247933 & -2.223478 \\
\hline Hiawa & Farmlands/Shrubs & 5.6247933 & -2.223478 \\
\hline Hiawa & Farmlands/Shrubs & 5.6247933 & -2.223478 \\
\hline Hiawa & Waterbodies & 5.6247933 & -2.223478 \\
\hline Hiawa & Farmlands/Shrubs & 5.6247933 & -2.223478 \\
\hline Hiawa & Built-up & 5.6247933 & -2.223478 \\
\hline Huni Ano & Farmlands/Shrubs & 5.6247933 & -2.223478 \\
\hline Huni Ano & Forest & 5.6247933 & -2.223478 \\
\hline Huni Ano & Built-up & 5.6247933 & -2.223478 \\
\hline Huni Ano & Built-up & 5.6247933 & -2.223478 \\
\hline Huni Ano & Bare land & 5.6247933 & -2.223478 \\
\hline
\end{tabular}

Page 25/35 


\begin{tabular}{|c|c|c|c|}
\hline Huni Ano & Bare land & 5.6247933 & -2.223478 \\
\hline Jomoro Enchi & Farmlands/Shrubs & 5.7651643 & -2.5994983 \\
\hline Jomoro Enchi & Built-up & 5.7604142 & -2.5922528 \\
\hline Jomoro Enchi & Farmlands/Shrubs & 5.7602436 & -2.5903879 \\
\hline Jomoro Enchi & Bare land & 5.7605395 & -2.5881754 \\
\hline Jomoro Enchi & Forest & 5.7623849 & -2.5777847 \\
\hline K Boateng & Forest & 5.6628668 & -2.2963313 \\
\hline K Boateng & Forest & 5.6604762 & -2.2955102 \\
\hline K Boateng & Built-up & 5.6531527 & -2.2918049 \\
\hline K Boateng & Forest & 5.6485145 & -2.2744123 \\
\hline K Boateng & Forest & 5.6315369 & -2.2410895 \\
\hline K Boateng & Bare land & 5.6300531 & -2.2269643 \\
\hline K Boateng & Farmlands/Shrubs & 5.6247933 & -2.223478 \\
\hline K Boateng & Farmlands/Shrubs & 5.7375434 & -2.3802338 \\
\hline K Boateng & Forest & 5.7247883 & -2.3644376 \\
\hline K Boateng & Forest & 5.7269672 & -2.3665777 \\
\hline K Boateng & Forest & 5.7245246 & -2.3621037 \\
\hline K Boateng & Farmlands/Shrubs & 5.7242997 & -2.3600675 \\
\hline K Boateng & Farmlands/Shrubs & 5.7198934 & -2.3546139 \\
\hline Mando Amenfi & Forest & 5.64882 & -2.276025 \\
\hline Mando Amenfi & Forest & 5.6460341 & -2.2694278 \\
\hline Mando Amenfi & Built-up & 5.6434423 & -2.268532 \\
\hline Mando Amenfi & Forest & 5.6321434 & -2.2427021 \\
\hline Mando Amenfi & Forest & 5.6306463 & -2.2390589 \\
\hline Mempeasem & Bare land & 5.2214854 & -2.0202423 \\
\hline Mempeasem & Bare land & 5.2192204 & -2.0212039 \\
\hline Mempeasem & Farmlands/Shrubs & 5.2066628 & -2.0281055 \\
\hline Mempeasem & Bare land & 5.1958116 & -2.0321357 \\
\hline Mempeasem & Farmlands/Shrubs & 5.1888986 & -2.036978 \\
\hline Mempeasem & Bare land & 5.1869638 & -2.0384229 \\
\hline Mempeasem & Built-up & 5.182622 & -2.0415238 \\
\hline Nsuaem & Bare land & 4.8925694 & -1.8928628 \\
\hline Nsuaem & Farmlands/Shrubs & 4.8920418 & -1.888316 \\
\hline Nsuaem & Bare land & 4.8934211 & -1.834469 \\
\hline Nsuaem & Forest & 5.0568485 & -2.0970696 \\
\hline Nsuaem & Built-up & 5.030064 & -2.08665 \\
\hline Nsuaem & Farmlands/Shrubs & 5.0052443 & -2.0738555 \\
\hline Nsuaem & Built-up & 5.0027138 & -2.0252646 \\
\hline Nsuaem & Forest & 4.9921162 & -2.0182028 \\
\hline Nsuaem & Forest & 5.0043177 & -2.0703931 \\
\hline Nsuaem & Built-up & 5.004357 & -2.0357449 \\
\hline Nsuaem & Forest & 4.9975721 & -2.0230747 \\
\hline Nsuaem & Forest & 4.9957281 & -2.0220048 \\
\hline Nsuaem & Farmlands/Shrubs & 4.9840114 & -2.0080939 \\
\hline Nya & Farmlands/Shrubs & 5.7872277 & -2.6717185 \\
\hline Nya & Built-up & 5.3253847 & -1.9825107 \\
\hline Nya & Bare land & 5.7346415 & -2.3773603 \\
\hline Nya & Forest & 5.7064848 & -2.3246181 \\
\hline Nyametiase & Farmlands/Shrubs & 5.6247933 & -2.223478 \\
\hline Nyametiase & Built-up & 5.6247933 & -2.223478 \\
\hline Nyametiase & Farmlands/Shrubs & 5.6247933 & -2.223478 \\
\hline Nyametiase & Built-up & 5.6247933 & -2.223478 \\
\hline Nyametiase & Built-up & 5.6247933 & -2.223478 \\
\hline Nyametiase & Built-up & 5.6247933 & -2.223478 \\
\hline Nyametiase & Bare land & 5.6247933 & -2.223478 \\
\hline Nyametiase & Bare land & 5.7302564 & -2.372268 \\
\hline Nyametiase & Farmlands/Shrubs & 5.6584121 & -2.2941531 \\
\hline Nyametiase & Farmlands/Shrubs & 5.6522835 & -2.2882657 \\
\hline Nyametiase & Forest & 5.6247933 & -2.223478 \\
\hline Nyametiase & Waterbodies & 5.6247933 & -2.223478 \\
\hline Nyametiase & Farmlands/Shrubs & 5.6247933 & -2.223478 \\
\hline Nyametiase & Built-up & 5.6247933 & -2.223478 \\
\hline Nyametiase & Built-up & 5.6247933 & -2.223478 \\
\hline Nyametiase & Farmlands/Shrubs & 5.6247933 & -2.223478 \\
\hline Pantoso & Waterbodies & 5.7698637 & -2.5709487 \\
\hline Pantoso & Built-up & 5.7703918 & -2.568473 \\
\hline Pantoso & Forest & 5.7708073 & -2.5604985 \\
\hline Pantoso & Farmlands/Shrubs & 5.7713379 & -2.5591144 \\
\hline Pantoso & Built-up & 5.7724658 & -2.5334899 \\
\hline Pantoso & Built-up & 5.772795 & -2.540285 \\
\hline Pantoso & Built-up & 5.7743097 & -2.5313814 \\
\hline Pantoso & Farmlands/Shrubs & 5.7731143 & -2.5196096 \\
\hline
\end{tabular}

Page 26/35 


\begin{tabular}{|c|c|c|c|}
\hline Pantoso & Farmlands/Shrubs & 5.7719406 & -2.5138868 \\
\hline Pantoso & Bare land & 5.7688464 & -2.5098793 \\
\hline Pantoso & Farmlands/Shrubs & 5.7674725 & -2.5011995 \\
\hline Petepon & Built-up & 5.6247933 & -2.223478 \\
\hline Petepon & Built-up & 5.6247933 & -2.223478 \\
\hline Petepon & Built-up & 5.6247933 & -2.223478 \\
\hline Petepon & Farmlands/Shrubs & 5.6247933 & -2.223478 \\
\hline Petepon & Forest & 5.6247933 & -2.223478 \\
\hline Petepon & Built-up & 5.6247933 & -2.223478 \\
\hline Petepon & Built-up & 5.6247933 & -2.223478 \\
\hline Petepon & Built-up & 5.6247933 & -2.223478 \\
\hline Petepon & Forest & 5.6247933 & -2.223478 \\
\hline Petepon & Waterbodies & 5.6247933 & -2.223478 \\
\hline Petepon & Bare land & 5.6247933 & -2.223478 \\
\hline Petepon & Built-up & 5.6247933 & -2.223478 \\
\hline Petepon & Farmlands/Shrubs & 5.6394875 & -2.2613292 \\
\hline Petepon & Built-up & 5.6326585 & -2.2356167 \\
\hline Petepon & Forest & 5.6337014 & -2.2329625 \\
\hline Petepon & Forest & 5.6281978 & -2.224905 \\
\hline Petepon & Farmlands/Shrubs & 5.6247933 & -2.223478 \\
\hline Petepon & Built-up & 5.6247933 & -2.223478 \\
\hline Petepon & Farmlands/Shrubs & 5.6247933 & -2.223478 \\
\hline Petepon & Farmlands/Shrubs & 5.6247933 & -2.223478 \\
\hline Samahu & Built-up & 5.6247933 & -2.223478 \\
\hline Sekondi & Bare land & 4.981071746 & -1.703316041 \\
\hline Sekondi & Built-up & 4.98384578 & -1.690543684 \\
\hline Sekondi & Built-up & 4.986396853 & -1.686009185 \\
\hline Sekondi & Forest & 4.989351823 & -1.684250038 \\
\hline Sekondi & Built-up & 4.993914186 & -1.681770255 \\
\hline Sekondi & Built-up & 4.995510854 & -1.680833392 \\
\hline Sekondi & Waterbodies & 4.996225596 & -1.680481145 \\
\hline Sekondi & Bare land & 5.011633193 & -1.667837511 \\
\hline Sekondi & Farmlands/Shrubs & 5.017023195 & -1.664991567 \\
\hline Sekondi & Farmlands/Shrubs & 5.033433115 & -1.662371466 \\
\hline Sekondi & Bare land & 5.034443731 & -1.661812642 \\
\hline Sekondi & Bare land & 5.039296842 & -1.659257281 \\
\hline Sekondi & Built-up & 5.046485183 & -1.659906999 \\
\hline Sekondi & Built-up & 5.050055196 & -1.65992817 \\
\hline Sekondi & Farmlands/Shrubs & 5.053968141 & -1.659103704 \\
\hline Sekondi & Bare land & 5.056765328 & -1.65834984 \\
\hline Sekondi & Bare land & 5.059147487 & -1.657683855 \\
\hline Sekondi & Farmlands/Shrubs & 5.061423299 & -1.657446956 \\
\hline Sekondi & Farmlands/Shrubs & 5.063263997 & -1.657815816 \\
\hline Sekondi & Built-up & 5.064566773 & -1.657765225 \\
\hline Sekondi & Farmlands/Shrubs & 5.066531208 & -1.657236498 \\
\hline Sekondi & Farmlands/Shrubs & 5.072636144 & -1.659077986 \\
\hline Sekondi & Farmlands/Shrubs & 5.08231858 & -1.656875289 \\
\hline Sekondi & Bare land & 5.083264577 & -1.656258935 \\
\hline Sekondi & Built-up & 5.08836956 & -1.650408756 \\
\hline Sekondi & Waterbodies & 5.088590326 & -1.649589901 \\
\hline Sekondi & Waterbodies & 5.089008602 & -1.648259838 \\
\hline Sekondi & Farmlands/Shrubs & 5.092449905 & -1.644865958 \\
\hline Sekondi & Bare land & 5.094907875 & -1.642610056 \\
\hline Sekondi & Bare land & 5.100080991 & -1.639969148 \\
\hline Sekondi & Forest & 5.105918685 & -1.636545206 \\
\hline Sekondi & Forest & 5.10676712 & -1.635252277 \\
\hline Simpa & Forest & 4.9671108 & -1.982734 \\
\hline Simpa & Farmlands/Shrubs & 4.8961903 & -1.9613612 \\
\hline Simpa & Forest & 5.124434 & -2.0996887 \\
\hline Simpa & Forest & 5.1208471 & -2.1004563 \\
\hline Simpa & Farmlands/Shrubs & 5.1183377 & -2.1031483 \\
\hline Simpa & Built-up & 5.1116846 & -2.1095497 \\
\hline Simpa & Forest & 5.0028389 & -2.065024 \\
\hline Simpa & Forest & 5.0019133 & -2.0579305 \\
\hline Simpa & Built-up & 5.0048309 & -2.0312886 \\
\hline Simpa & Built-up & 5.0000172 & -2.0241244 \\
\hline Simpa & Forest & 4.9945834 & -2.021352 \\
\hline Simpa & Forest & 4.9880901 & -2.0132058 \\
\hline Simpa & Forest & 4.9775376 & -1.9999298 \\
\hline Simpa & Forest & 4.964483 & -1.9805508 \\
\hline Simpa & Forest & 4.9450753 & -1.9787513 \\
\hline Simpa & Farmlands/Shrubs & 4.9323343 & -1.9775734 \\
\hline
\end{tabular}

Page 27/35 


\begin{tabular}{|c|c|c|c|}
\hline Simpa & Built-up & 4.9228056 & -1.9781813 \\
\hline Simpa & Waterbodies & 4.9195849 & -1.9782022 \\
\hline Simpa & Built-up & 4.8998317 & -1.969145 \\
\hline Simpa & Built-up & 4.8996714 & -1.9285046 \\
\hline Simpa & Farmlands/Shrubs & 4.8916177 & -1.8751595 \\
\hline Simpa & Bare land & 4.8916025 & -1.873962 \\
\hline Simpa & Built-up & 4.8933575 & -1.8359136 \\
\hline Simpa & Bare land & 4.8970706 & -1.8054882 \\
\hline Simpa & Waterbodies & 4.9044748 & -1.8024535 \\
\hline Simpa & Built-up & 4.9111059 & -1.7905588 \\
\hline Simpa & Built-up & 5.1067582 & -2.1111054 \\
\hline Simpa & Farmlands/Shrubs & 5.074902 & -2.1037855 \\
\hline Simpa & Built-up & 5.0593333 & -2.0978323 \\
\hline Simpa & Forest & 5.0351012 & -2.0869449 \\
\hline Simpa & Forest & 5.0141916 & -2.0857272 \\
\hline Sureso & Farmlands/Shrubs & 5.7421022 & -2.3846263 \\
\hline Sureso & Farmlands/Shrubs & 5.7403294 & -2.3823464 \\
\hline Sureso & Built-up & 5.7324284 & -2.374951 \\
\hline Sureso & Farmlands/Shrubs & 5.7288055 & -2.3696199 \\
\hline Sureso & Farmlands/Shrubs & 5.7151425 & -2.3406464 \\
\hline Sureso & Forest & 5.7171815 & -2.3309613 \\
\hline Takoradi & Built-up & 4.902413017 & -1.757937547 \\
\hline Takoradi & Built-up & 4.900615895 & -1.753039743 \\
\hline Takoradi & Bare land & 4.901706137 & -1.753217088 \\
\hline Takoradi & Built-up & 4.902714391 & -1.761149546 \\
\hline Takoradi & Built-up & 4.917378186 & -1.768600407 \\
\hline Takoradi & Built-up & 4.931854443 & -1.762745326 \\
\hline Takoradi & Bare land & 4.936431517 & -1.756667313 \\
\hline Takoradi & Farmlands/Shrubs & 4.943385074 & -1.752279565 \\
\hline Takoradi & Waterbodies & 4.959675202 & -1.736686621 \\
\hline Takoradi & Built-up & 4.965007662 & -1.733043819 \\
\hline Takoradi & Built-up & 4.966636212 & -1.728443967 \\
\hline Takoradi & Built-up & 4.966824295 & -1.724046787 \\
\hline Takoradi & Built-up & 4.973188531 & -1.716764645 \\
\hline Takoradi & Bare land & 4.976964337 & -1.715101399 \\
\hline Takoradi & Built-up & 5.0050532 & -2.028768 \\
\hline Takoradi & Forest & 4.9658955 & -1.9816799 \\
\hline Takoradi & Farmlands/Shrubs & 4.9011742 & -1.9221394 \\
\hline Takoradi & Bare land & 4.892615 & -1.8518078 \\
\hline Takoradi & Built-up & 4.8931455 & -1.8266697 \\
\hline Takoradi & Forest & 5.0862533 & -2.108585 \\
\hline Takoradi & Forest & 5.080348 & -2.1092255 \\
\hline Takoradi & Built-up & 5.0691614 & -2.0982327 \\
\hline Takoradi & Forest & 5.0679345 & -2.0973289 \\
\hline Takoradi & Forest & 5.0619644 & -2.0973 \\
\hline Takoradi & Forest & 5.0520178 & -2.093893 \\
\hline Takoradi & Forest & 5.0018325 & -2.0598543 \\
\hline Takoradi & Forest & 5.0027671 & -2.0503787 \\
\hline Takoradi & Forest & 5.0034252 & -2.0442872 \\
\hline Takoradi & Forest & 4.96908 & -1.98471 \\
\hline Takoradi & Forest & 4.9403308 & -1.978419 \\
\hline Takoradi & Built-up & 4.9096871 & -1.9731285 \\
\hline Takoradi & Built-up & 4.9094282 & -1.7947036 \\
\hline Takoradi & Forest & 5.0644825 & -2.0966642 \\
\hline Takoradi & Forest & 5.0499747 & -2.0925606 \\
\hline Takoradi & Forest & 5.0021585 & -2.0558429 \\
\hline Takoradi & Forest & 5.0036057 & -2.0420698 \\
\hline Takoradi & Farmlands/Shrubs & 5.0041353 & -2.0374857 \\
\hline Takoradi & Built-up & 5.004322 & -2.0265984 \\
\hline Takoradi & Farmlands/Shrubs & 4.9359189 & -1.9779885 \\
\hline Takoradi & Farmlands/Shrubs & 4.9016832 & -1.9075507 \\
\hline Takoradi & Built-up & 4.9119349 & -1.7841684 \\
\hline Takoradi & Built-up & 4.9100242 & -1.7808045 \\
\hline Takoradi & Built-up & 4.9082006 & -1.7778442 \\
\hline Takoradi & Built-up & 4.9033652 & -1.7693175 \\
\hline Takoradi & Built-up & 4.8985936 & -1.7529065 \\
\hline Tarkwa & Built-up & 5.6247933 & -2.223478 \\
\hline Tarkwa & Built-up & 5.6247933 & -2.223478 \\
\hline Tarkwa & Built-up & 5.3278937 & -1.9816643 \\
\hline Tarkwa & Built-up & 5.7137202 & -2.3274828 \\
\hline Tarkwa & Forest & 5.6527617 & -2.2844424 \\
\hline Tarkwa & Bare land & 5.6446488 & -2.2689285 \\
\hline
\end{tabular}

Page 28/35 


\begin{tabular}{|l|l|r|r|} 
Tarkwa & Built-up & 5.6399536 & -2.2628259 \\
\hline Tarkwa & Built-up & 5.6364597 & -2.256053 \\
\hline Tarkwa & Forest & 5.6486788 & -2.2775177 \\
\hline Tarkwa & Farmlands/Shrubs & 5.625145 & -2.2238767 \\
\hline Tarkwa & Farmlands/Shrubs & 5.6247933 & -2.223478 \\
\hline Tarkwa & Forest & 5.6247933 & -2.223478 \\
\hline Tarkwa & Farmlands/Shrubs & 5.6247933 & -2.223478 \\
\hline Tarkwa & Farmlands/Shrubs & 5.6247933 & -2.223478 \\
\hline Tarkwa & Bare land & 5.6247933 & -2.223478 \\
\hline Tarkwa & Farmlands/Shrubs & 5.6247933 & -2.223478 \\
\hline Wangara Krom & Farmlands/Shrubs & 5.6247933 & -2.223478 \\
\hline Wangara Krom & Farmlands/Shrubs & 5.6247933 & -2.223478 \\
\hline Wangara Krom & Farmlands/Shrubs & 5.6247933 & -2.223478 \\
\hline Yiwabra Nkwanta & Built-up & 5.7959186 & -2.6766276 \\
\hline Yiwabra Nkwanta & Bare land & 5.7905741 & -2.6735574 \\
\hline Yiwabra Nkwanta & Farmlands/Shrubs & 5.7821798 & -2.6614652 \\
\hline Yiwabra Nkwanta & Built-up & 5.7800707 & -2.6585705 \\
\hline Yiwabra Nkwanta & Farmlands/Shrubs & 5.7806367 & -2.6508106 \\
\hline Yiwabra Nkwanta & Bare land & 5.7805307 & -2.6490029 \\
\hline Yiwabra Nkwanta & Forest & 5.7778537 & -2.6376516 \\
\hline Yiwabra Nkwanta & Farmlands/Shrubs & 5.7761135 & -2.6308095 \\
\hline
\end{tabular}

\begin{tabular}{|l|r|} 
Features & Number of Total Samples \\
\hline Forest & $\mathbf{1 0 4}$ \\
\hline Farmlands/Shrubs & $\mathbf{1 5 3}$ \\
\hline Built-up & $\mathbf{1 7 7}$ \\
\hline Bare land & $\mathbf{7 0}$ \\
\hline Waterbodies & $\mathbf{2 0}$ \\
\hline Total & 524 \\
\hline
\end{tabular}

\section{Figures}

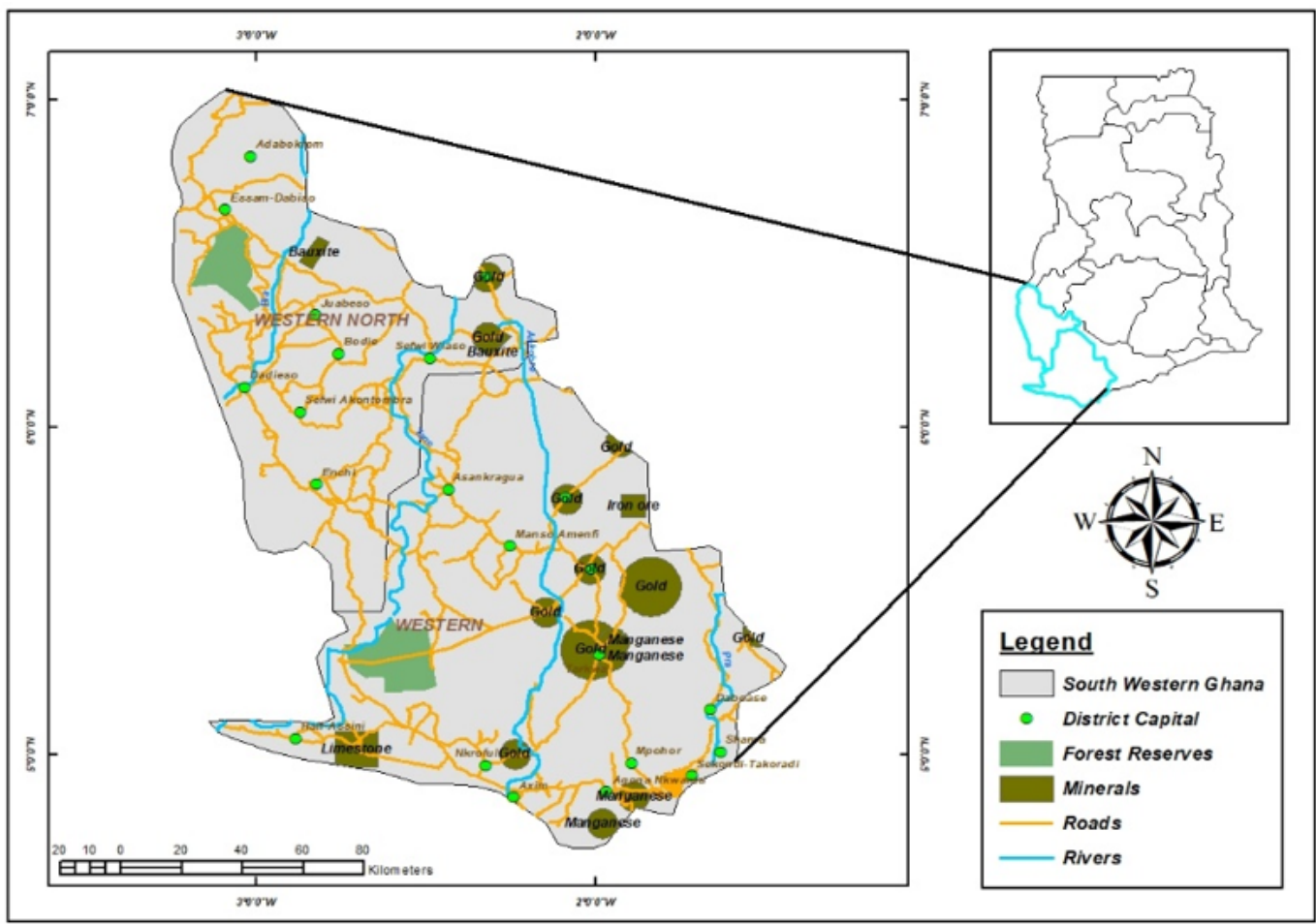

Figure 1

Location of the study area 


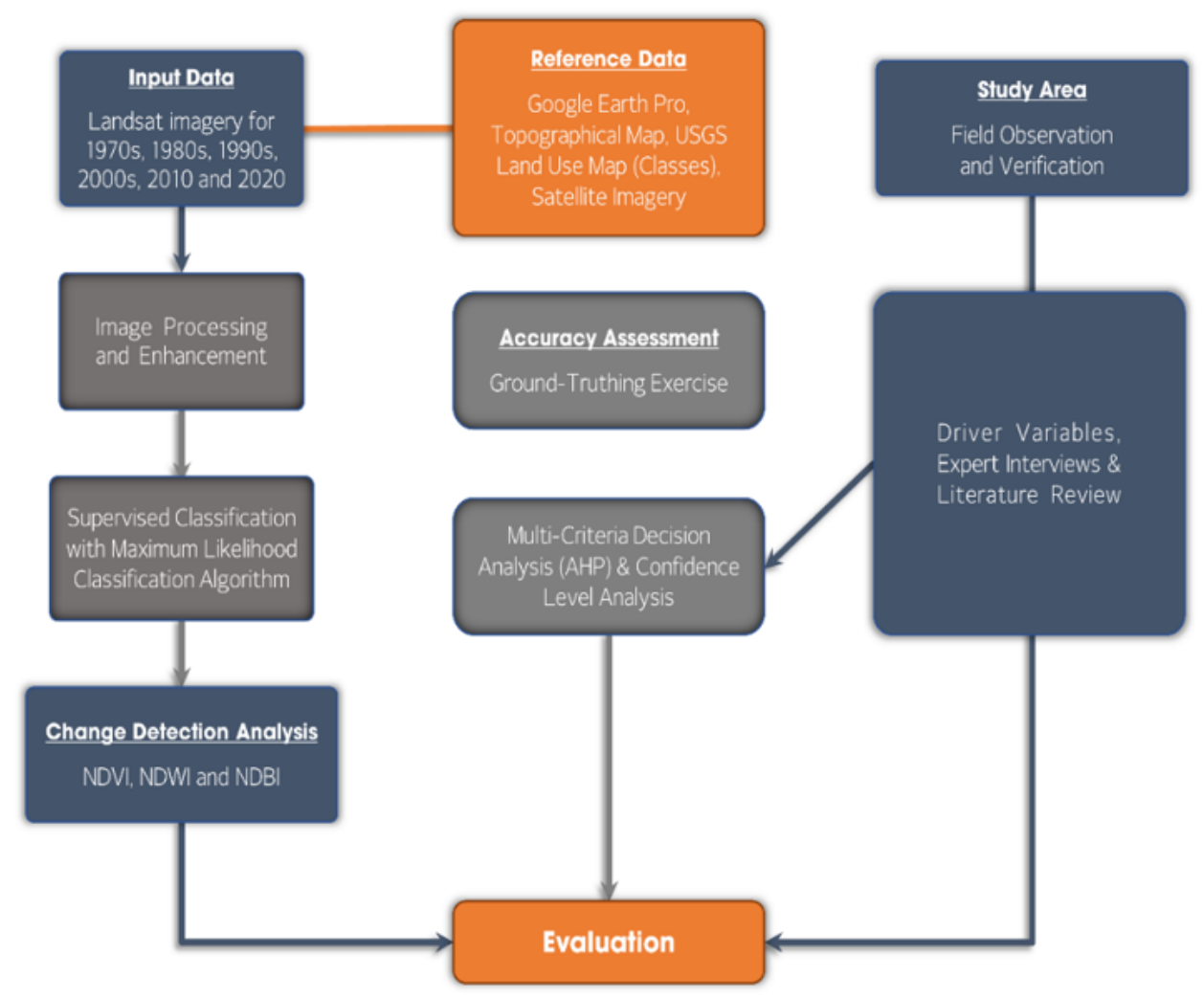

Figure 2

Flow-chat designed for this study

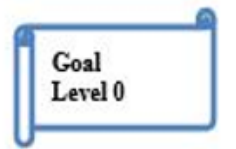

Drivers influencing LUCC \& Land degradation
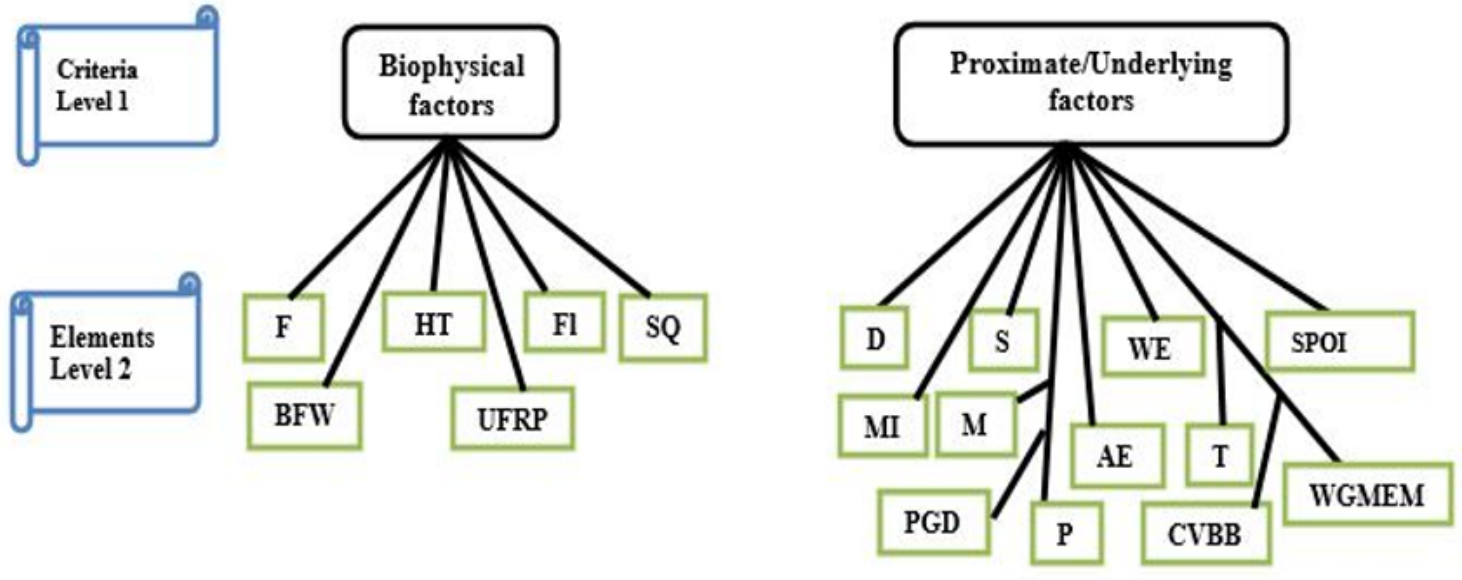

Figure 3

AHP model of factors influencing LUCC and land degradation 


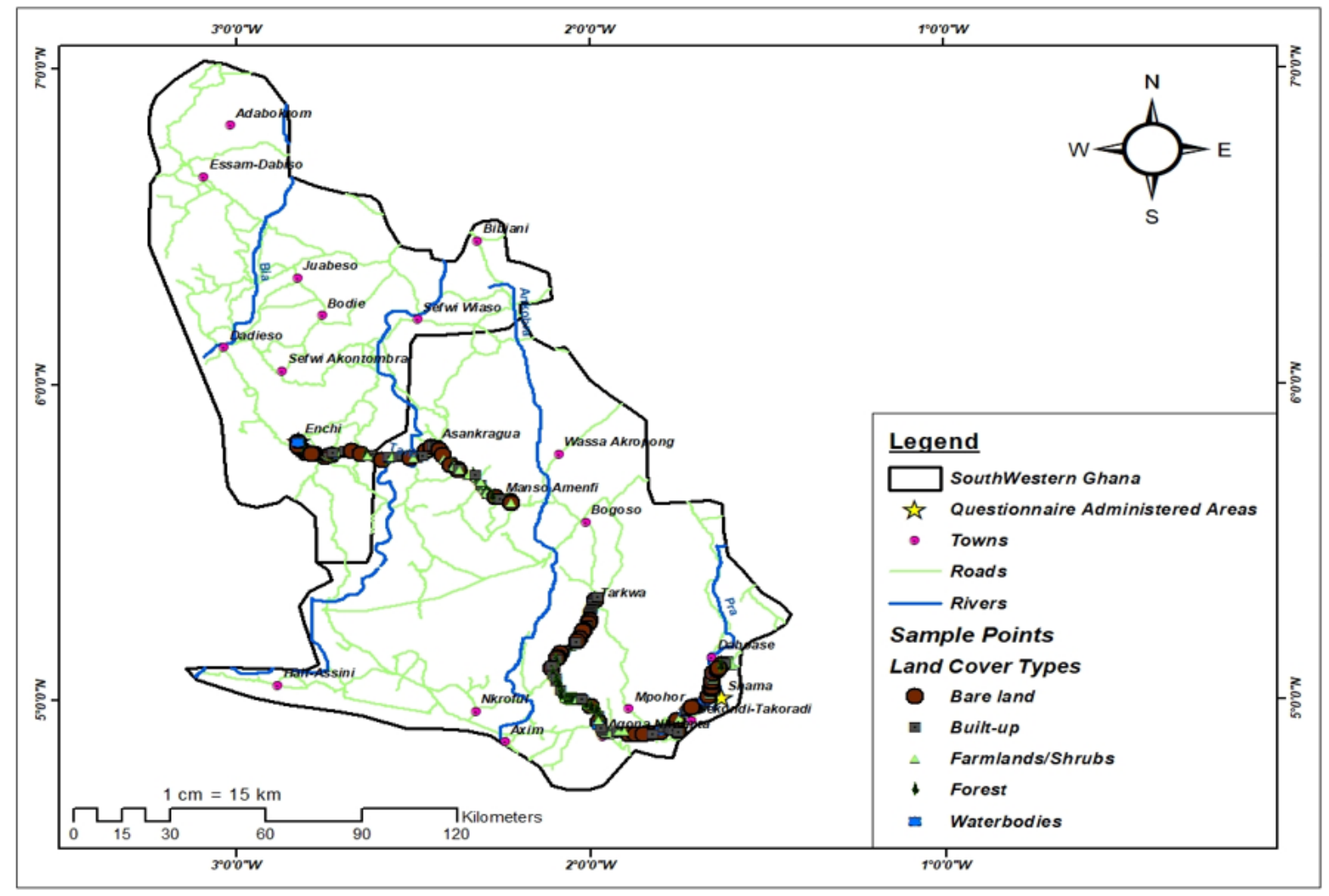

Figure 4

Geographical map depicting sample locations during the ground-truthing exercise

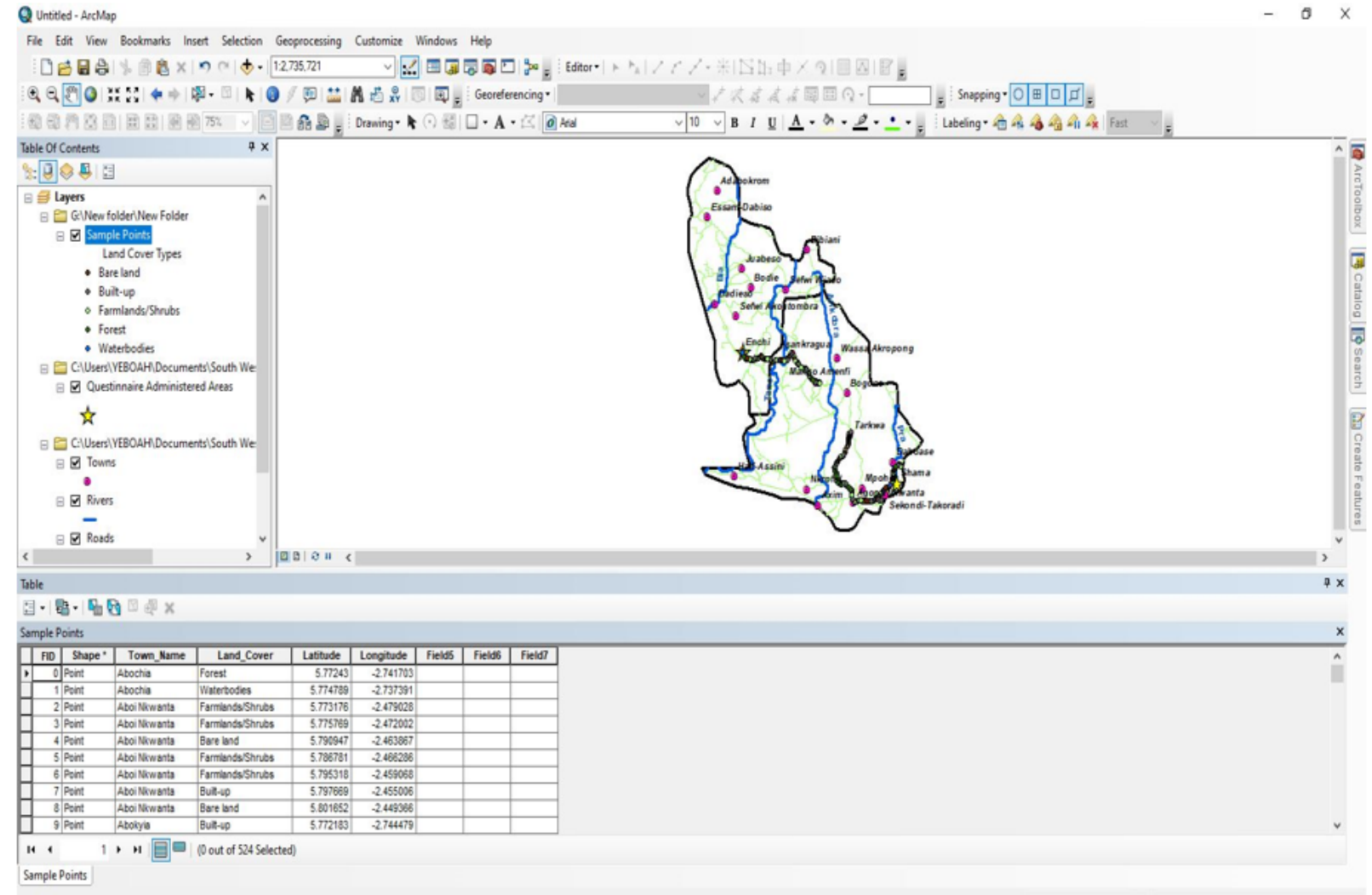

Figure 5 


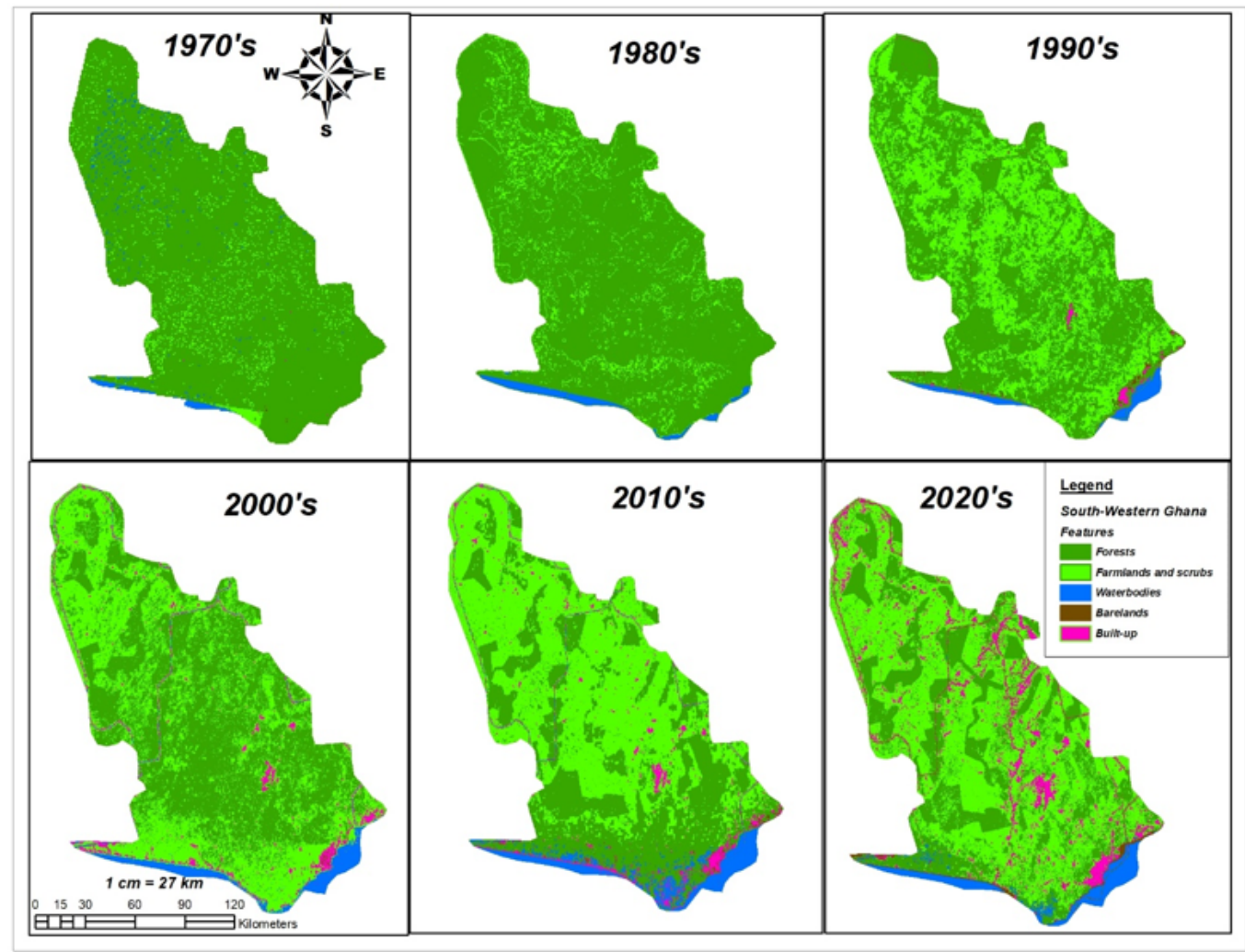

\section{Figure 6}

LUCC over the study period (1970-2020) in Southwestern Ghana.

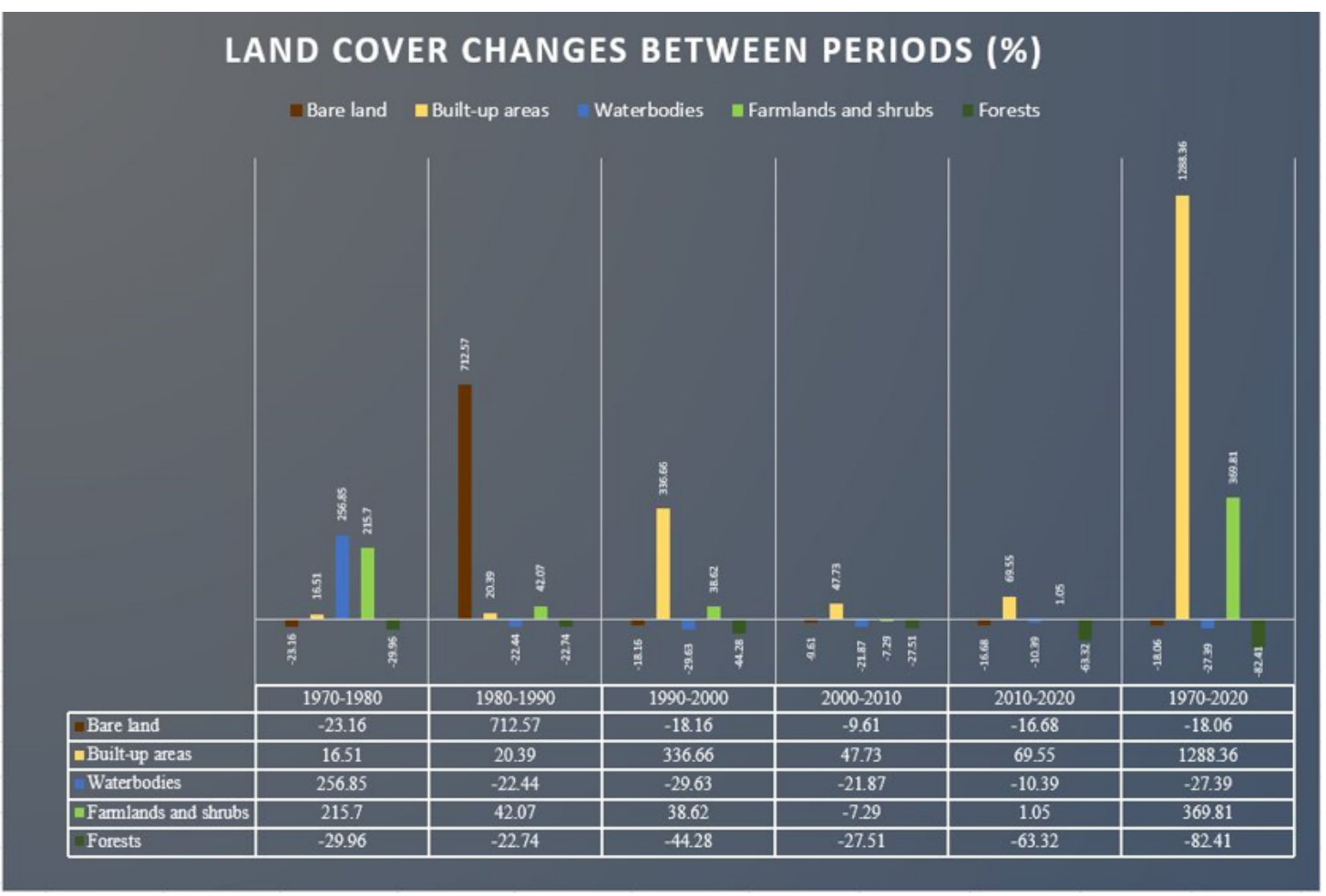

Figure 7

Land cover changes between periods (\%) 


\section{Rate and magnitude of change (sq. $\mathrm{km})$}

15000

10000

5000

0

$-239.48$

$\longrightarrow$

6896.36

$-5000$

Built-up

Waterbodies

Forests

$-10000$

$-15000$

$-16739.92$

$-20000$

Figure 8

Rate and magnitude of change (sq.km) over the past 50 years in Southwestern Ghana

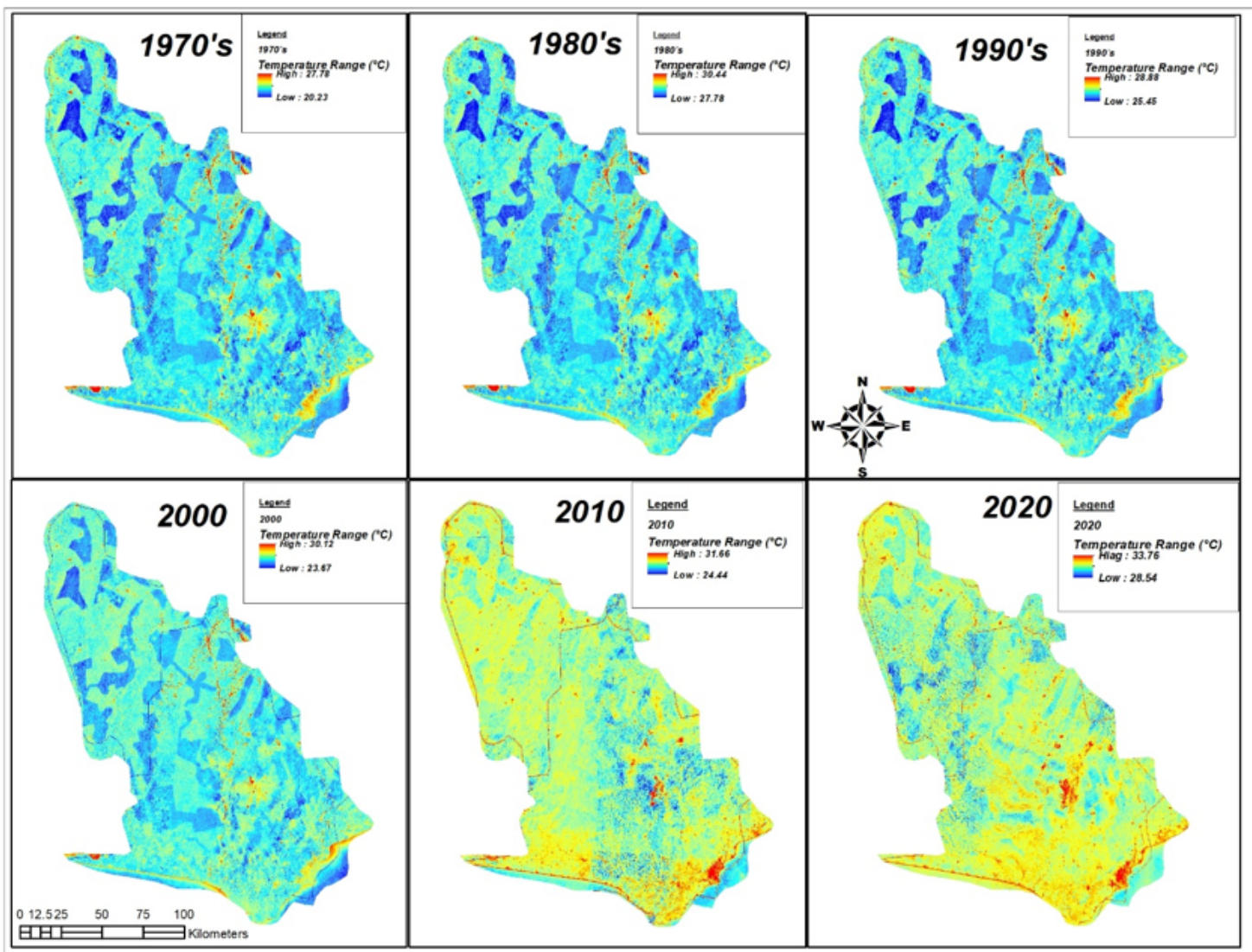

Figure 9

Temperature analysis over the study period (1970-2020) in Southwestern Ghana. 


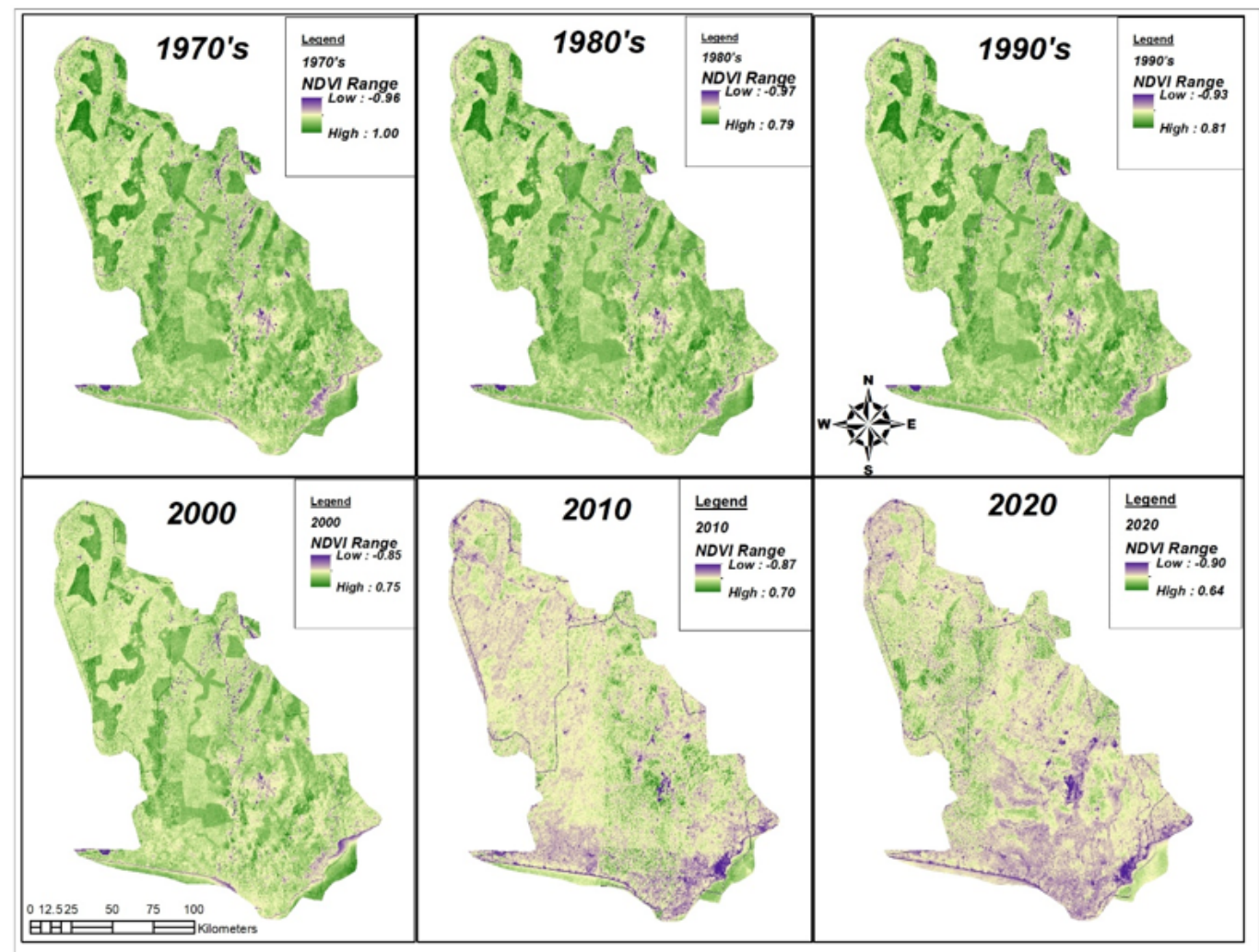

Figure 10

Changes in NDVI over the study period (1970-2020) in Southwestern Ghana.

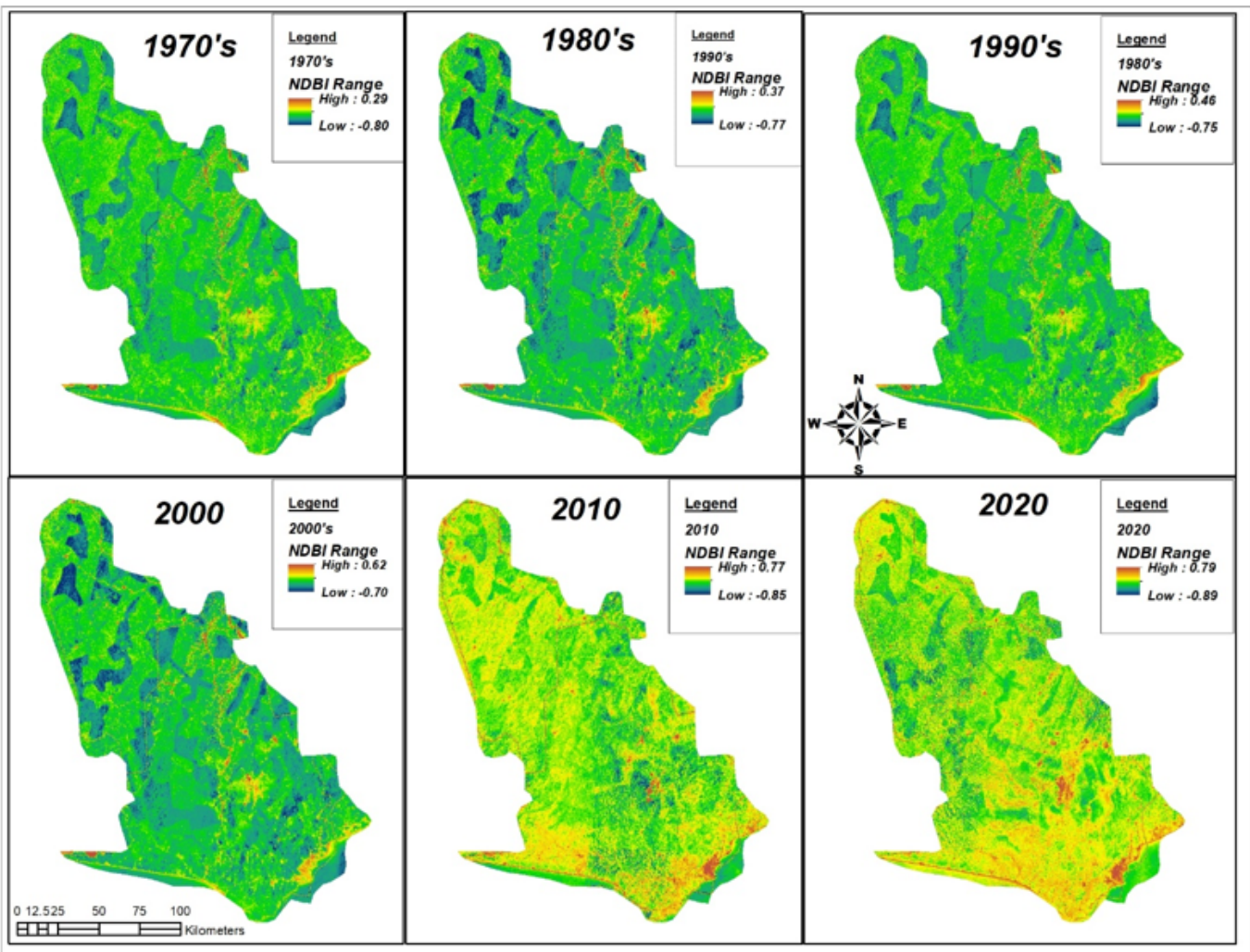

Figure 11

Changes in NDBI over the study period (1970-2020) in SW Ghana. 


\section{Supplementary Files}

This is a list of supplementary files associated with this preprint. Click to download.

- SupplementaryfileENGENOTPARTOFMANUSCRIPT.docx 